\title{
Through the Extremist Lens: Uncovering the Correlation Between Domestic Right- Wing Extremist Ideology and Violence in the United States from 2000 to 2020
}

\author{
By J.J. Brookhouser
}

\begin{abstract}
Domestic right-wing extremist violence has been increasing since 9/11/2001, outpacing federal recognition of the problem. Preoccupation with Islamic terrorism is only a partial explanation of this shortfall, institutional barriers and an increasingly mainstream political salience of domestic right-wing extremist ideology create serious obstacles to efforts at countering violent extremism. This study presents a clear relationship between domestic right-wing extremist ideology and violence in order to inform an effective counter violent extremism strategy. A grounded theory approach was used to analyze the expressed ideologies of domestic right-wing extremist attackers in the United States from 2000 to 2020 before comparing them to the number of deaths resulting from their attacks to reveal the correlation between ideology and the number of deaths. Qualitative data gathered from primary sources cited in news media archives vetted and referenced by the Global Terrorism Database (GTD) were theoretically coded to develop a set of aspects of domestic right-wing extremist ideology which were compared to quantitative data on the number of deaths gathered from the GTD. Comparison of aspects of ideology to the number of deaths showed that the 'attacker justified violence' aspect of ideology correlates significantly at a .05 degree of significance. Significant correlation between other aspects of ideology and the number of deaths, though prevalent, remain uncertain due to the small size of associated samples.
\end{abstract}

Keywords: Right Wing, Extremism, Violence, Ideology, United States, Terrorism 


\title{
A través de la lente extremista: descubriendo la correlación entre la ideología extremista de derecha doméstica y la violencia en los Estados Unidos de 2000 a 2020
}

\begin{abstract}
RESUMEN
La violencia doméstica de extrema derecha ha ido en aumento desde el 11 de septiembre de 2001, superando el reconocimiento federal del problema. La preocupación por el terrorismo islámico es sólo una explicación parcial de este déficit, las barreras institucionales y una creciente relevancia política de la ideología extremista de derecha nacional crean serios obstáculos a los esfuerzos por contrarrestar el extremismo violento. Este estudio presenta una relación clara entre la ideología de extrema derecha doméstica y la violencia con el fin de informar una estrategia eficaz contra el extremismo violento. Se utilizó un enfoque de teoría fundamentada para analizar las ideologías expresadas por los atacantes extremistas de derecha en los Estados Unidos de 2000 a 2020 antes de compararlas con el número de muertes resultantes de sus ataques para revelar la correlación entre la ideología y el número de muertes. Los datos cualitativos recopilados de fuentes primarias citados en archivos de medios de comunicación examinados y referenciados por Global Terrorism Database (GTD) se codificaron teóricamente para desarrollar un conjunto de aspectos de la ideología nacional de extrema derecha que se compararon con datos cuantitativos sobre el número de muertes recopiladas. del GTD. La comparación de los aspectos de la ideología con el número de muertes mostró que el aspecto de la ideología de "violencia justificada por el atacante" se correlaciona significativamente con un grado de importancia de .05. La correlación significativa entre otros aspectos de la ideología y el número de muertes, aunque prevalente, sigue siendo incierta debido al pequeño tamaño de las muestras asociadas.
\end{abstract}

Palabras clave: Derecha, Extremismo, Violencia, Ideología, Estados Unidos. 


\section{透过极端主义视角: 揭开2000-2020年间美国 国内右翼极端主义思想和暴力之间的关联}

\section{摘要}

自2001年9/11事件起, 美国国内右翼极端主义暴力情况便不 断增加, 超出了联邦政府对该问题的认识。将其与伊斯兰极 端主义相联系的预设仅仅是造成这一认识不足的原因之一，

制度障碍和变得日益主流的国内右翼极端主义思想的政治突 出性, 为一系列用于反暴力极端主义所作的努力制造了严峻 阻碍。本文呈现了国内右翼极端主义思想和暴力之间的清晰 关系, 以期形成一项有效的反暴力极端主义战略。运用扎根 理论方法, 分析2000-2020年美国国内右翼极端主义袭击者所 表现的思想, 随后将分析结果与由暴力袭击产生的死亡人数 加以比较，以期揭开思想与死亡数量之间的关联。从经过全 球恐怖主义数据库 (GTD) 审查和参考的、由新闻媒体库所引 用的原始数据中提取定性数据, 对定性数据进行理论编码, 以期提出国内右翼极端主义思想的一系列观点, 并将这些观 点与死亡数量 (从GTD获得) 的定量数据相比较。思想观点与 死亡数量的比较表明, “由袭击者造成的暴力”（attacker justified violence）这一思想观点在显著性水平为 0.05 时呈 显著相关。其他思想观点和死亡数量之间的显著相关性虽然 也存在，但因样本量小而不确定。

关键词：右翼，极端主义，暴力，思想，美国

\section{Introduction}

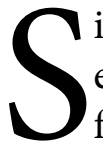

ince 2000, domestic right-wing extremism (RWE) has accounted for more attacks and more deaths in the United States than Islamic terrorism, but has received only a fraction of the attention. The threat continues to grow, spurred on by increasing injection of domestic right-wing (RW) extremist rhetoric into mainstream public politics and the power of the Internet and social media to disseminate minority views. The government response to domestic RWE is plagued by a preoccupation with the threat of Islamic terrorism, vocal political push-back, and a lack of inter-agency coordination including no standard lexicon of definitions. In 2009, the Homeland Security Report on domestic extremism named domestic RWE as a growing security threat facing the United States. The report specifically identified veterans re- 
turning from the Iraq and Afghanistan wars as potential targets for radicalization; however, due to massive public outcry led by a wave of domestic RW political commentators, the report was eventually retracted and an apology issued by the secretary to the Director of Homeland Security. This reaction is representative of the public reaction to the threat of domestic RWE in the United States as a whole.

Currently the United States is experiencing a period of unprecedented growth in domestic RW extremist group membership and activity. While it could be argued that this increase began as a response to the $9 / 11$ attacks, it has since been spurred on by conspiracy theories about the very legislation that resulted from that event. Exclusion and violence is the language of this ideology and increasingly mainstream politics have become its forum. Domestic RW extremist ideology has pervaded nearly every aspect of contemporary political discourse from social media to mainstream media to the White House to Congress. Ideological engagement is an integral part of any counter violent extremism strategy (CVE), but hate speech and incitements to violence should not be allowed air-time on the same media forums that disseminate legitimate political discourse. The latter represents constitutionally protected speech, the former does not. Any effective counter violent extremism strategy will need to take great pains in determining hate speech and incitements to violence from protected speech-failure to do so could damage one of the core tenets of American democracy. To facilitate greater understanding of the issue, this study clarifies the relationship between domestic RW extremist violence and the ideologies espoused by those who commit it, clearly identifying which aspects of ideology correlate with and contribute to the greatest number of deaths resulting from violent attacks.

This study examines domestic RW extremist attack data in the United States between 2000 and 2020 to determine the effect the attackers' ideologies have on the number of deaths resulting from their attacks. By first identifying the relevant aspects of ideology of each attacker and then comparing them to the number deaths resulting from the attack, correlations between specific aspects of domestic RW extremist ideology and the number of deaths are identified. Further analysis of these correlations informs future efforts at CVE in the United States by identifying the most violent aspects of domestic RW extremist ideology.

In order to investigate the relationship between ideology and violence, this study answers the following research question and tests the following hypothesis.

Research Question: How does the attackers' ideology affect the number of deaths resulting from domestic RW extremist attacks in the United States between 2000 and 2020 ?

Hypothesis: The attackers' ideology correlates with the number of deaths resulting from domestic RW extremist attacks in the United States between 2000 and 2020. 
This study seeks to clarify the relationship between ideology and the growing trend of domestic RW extremist violence in the United States between 2000 and 2020. Although numerous studies have examined domestic RW extremist violence and domestic RW extremist ideology, none have studied how violent incidents are shaped and driven by ideology. The legacy of this study is to identify which aspects of domestic RW extremist ideology correlate most closely with the number of deaths from extremist violence in the United States in order to better inform efforts at ideological engagement for the purpose of CVE.

\section{Literature Review}

7 he current view of domestic RWE in the United States is not a collection of radical groups as in international terrorism, but a fractured network of interlinking ideologies, borrowing aspects of each other's rhetoric to create a unique, interrelated constellation of views, the majority of which draw from a common background of racist, antisemitic and conspiratorial beliefs. However, each ideology is different, citing their own grievances, target populations, and associated rhetoric. This constellation is further complicated by varying degrees of extremism espoused by different members within each ideology, illustrated by the domestic RW extremist movement's adherence to the leaderless resistance model circulated in the United States by Louis Beam in the 1980s and '90s. Under this twopart model, non-violent public influ- encers create and disseminate domestic RW extremist ideological propaganda for consumption by their extremist counterparts while remaining protected from legal recourse by the First Amendment. Those extremists, motivated by propaganda disseminated online and increasingly through social and mainstream media, engage in violent action, carrying out the unstated suggestions of their legally protected counterparts. Recently this model played a key role in former President Trump's reelection strategy. Years of rhetoric sympathetic to domestic RW extremist groups and un-corroborated narratives of election fraud and corruption within the Democratic party fueled a resurgent domestic RW extremist movement, resulting in numerous planned and successful attacks including the Capitol attack of January $6^{\text {th }}, 2021$. However, little is known about the direct relationship between ideology and violence. How is violence influenced by ideology? How does the attackers' ideology affect the number of deaths resulting from domestic RW extremist attacks in the United States between 2000 and 2020? Current research on the topic of domestic RWE can be divided succinctly into one of five categories: government perceptions of domestic RWE, mainstream perceptions of domestic RWE, extremism and media, domestic RW extremist ideology, and domestic RW extremist organization.

\section{Government Perceptions of Domestic Right-wing Extremism}

Much of the current research on the topic of government perceptions of do- 
mestic RWE is dominated by the government's recognition of the problem and shortcomings in responding to it. Recognition of the problem has been slow in coming and has been led as much by local law enforcement departments as by federal agencies (Bjelopera, 2017; Cunningham, 2007). Domestic RW extremists share many of the same radicalizing factors as Islamic extremists including social, economic, political, psychological or religious influences (Carpenter et al., 2009). The current surge in Domestic RWE is attributed in part to current economic and political trends including the election of the nation's first African-American president and recent gun regulations (Southers, 2013; Center for American Progress, 2012). Specific attention was paid to the risk posed by veterans returning from the Afghanistan and Iraq wars being especially susceptible to radicalization due to the great difficulties they face in community reintegration or even by being targeted for recruitment by extremist groups due to their military skill set (Southers, 2013; Center for American Progress, 2012). Most actions toward CVE have been preoccupied with an exaggerated threat of Islamic homegrown terrorism, continuing a trend post $9 / 11$ that has plagued Intelligence Community analysis since the Murrah Federal building bombing in 1985 (Bjelopera, 2012; Corman, 2016; Sloan, 2016; Boggs \& Pollard, 2006). This is reflective of mainstream views of terrorism at large, even the definition of "domestic terrorism" in the U.S. Patriot Act is offered only as an addendum to the perceived greater threat of international terrorism (Quiney, 2007). Even as late as 2011, Federal CVE strategy focused on the threat of homegrown Islamic terrorism to the exclusion of other groups (Bjelopera, 2014; Empowering Local Partners to Prevent Violent Extremism in the United States, 2011). This is evident in efforts to stem the flow of funding to Islamist terror organizations, but a lack of programs targeting their domestic terror counterparts (Keatinge et al., 2019). This preoccupation with Islamic extremism seems especially misplaced in light of reports indicating Domestic RWE has accounted not only for more attacks than Islamic extremism, but also significantly more deaths in the US since 9/11 (Ducol et al., 2016; Center for American Progress, 2012). This trend is not unique to the United States either; during the period from 1998 to 2005 , domestic terrorism accounted for $80 \%$ of all terrorism deaths world-wide (Sanchez-Cuenca \& De La Calle, 2009). Part of this preoccupation may be due to the way Domestic RWE is conceived by federal security agencies.

Unlike international terrorism, there is no comprehensive list of domestic terrorist organizations nor of incidents of domestic terror; instead, they are organized into a loose list of threats based off of contributing ideologies (Alexander, 2017; Healy, 2010; Bjelopera, 2012 \& 2017). This may be due in part to constitutional conflicts between the First Amendment and the leaderless resistance model commonly used to distance violent Domestic RW extremists from ideological organizations exercising their right to free speech (Bjelopera, 2017). Further complicating any 
comprehensive federal response to Domestic RWE is a lack of standard legal terminology to identify and label terrorism in general and violent extremism in particular. Not only do the United States Department of State, Federal Bureau of Investigation, and Central Intelligence Agency all have different definitions of terrorism, but the term "terrorism" is often conflated with "extremism" in legal proceedings (Chermak et al., 2011; United States Code of Federal Regulations). While it is argued that this allows lawyers leeway in prosecuting violent ideological crimes, the resulting confusion in the application of the "terrorism" label is widespread (Bjelopera, 2017; Ecoterrorism and Lawlessness, 2002).

Exacerbating the issue of government disorganization is the surge in Domestic RW extremist activity since 2001. The number of hate groups grew nearly 50\% from 2001 to 2015, experiencing a dramatic but temporary uptick in 2011 (Alexander, 2017). More worrying, anti-government groups grew by nearly $700 \%$ between 2001 and 2015, peaking dramatically in 2012 (Alexander, 2017; Potok, 2016). The number of RW extremist incidents as a percentage of all attacks in the US grew from $6 \%$ in 2001 to $35 \%$ in 2010 (National Consortium for the Study of Terrorism and Responses to Terrorism, 2017). In the period from 2011 to 2015, Domestic RWE's share of violent incidents in the US shot up to 73\% (Corbin, 2017). Much of this increase in violence is attributed to a growing trend of "lone wolf" attackers among Domestic RW extremist incidents (Chan et al., 2013;
Hoffman, 2013). Tied to the use of the leaderless resistance model among Domestic RW extremists, various studies have identified literature promoting lone wolf tactics on every Domestic RW extremist website surveyed (Ray \& Marsh, 2001; Adams \& Roscigno, 2005). While the recognition of many misconceptions of Domestic RWE is unique to government, many of those same misconceptions are shared by the population at large.

\section{Mainstream Perceptions of Domestic Right-wing Extremism}

Mainstream perceptions of and discourse surrounding Domestic RWE are equally as disorganized and misled as those of government, exacerbated by hyperbolized representations in media and politics. Much like government conceptions of terrorism, mainstream perceptions of terrorism remain preoccupied with Islamic extremism so much so that the word "terrorist" conjures racialized images of Muslim extremists. This image, reinforced by two decades of media and Hollywood caricature, has led to the creation of a new suspect population within America at large (Boggs \& Pollard, 2006). Like Japanese-Americans during World War II, American Muslims have been uniquely subject not only "to murders, beatings, death threats and other intimidation(s)," but also to new legislation which allows racial profiling of non-white Muslims or suspected Muslims, creating in effect "a modern, technological version of the Japanese internment camps of the 1940s" (Earth First, 2001). As a re- 
sult, Githens-Mazer (2012) explains the shock of 9/11 and subsequent securitization of Islam has disallowed Muslims from engaging in radical non-violence in the west. Even the term "radicalization" has been associated with Islam post 9/11 in media and government communications (Horgan, 2005). These foreign conceptions of terror have culminated in a discourse dominated by fear of an alien "Other" in anti-terror legislation, the repercussions of which are shouldered by immigrants and asylum seekers "whose encroachment appears to make a besieged, deprived victim of the previously privileged native citizen" (Quiney, 2007). The USA Patriot Act allows for deportation of 'suspect' immigrants, requiring little more than the perception of a threat to national security (Quiney, 2007).

These conflations of non-citizens with the "Other" are best explained by Edward Said (1979) in that the colonization of the Middle East by European countries resulted in a binary juxtaposition of the Occident (the west) and the Orient (the east) in which the mirror image of any characteristic held by one group is reflected in polar opposite by the other (Saeed, 2007; Said, 1979; Said, 1981). Thus, western authors' attributions of law, progress and superiority to countries of the Occident were necessarily mirrored by the lawlessness, backwardness and inferiority of the countries of the Orient (Saeed, 2007; Said, 1979; Said, 1981). These arbitrary characterizations have largely survived in contemporary consciousness. It is informative to note that these notions of "othering" are prevalent in the ideology of both Domestic RWE and the Islamic State.

These binary perceptions of extremism extend beyond suspect populations and apply also to known terrorists. While white Christian terrorists are often portrayed in legal proceedings as human beings with childhoods, families and graduation photos, the same humanity is stripped from non-white Muslim perpetrators instantly, who are left only with mugshots and descriptions of their extremist ideology (Corbin, 2017). While white terrorists are immediately perceived as mentally ill victims of some prior trauma, non-white Muslim terrorists are not afforded the same benefit of the doubt - they are assumed to be religiously motivated members of a terrorist conspiracy (Corbin, 2017). Media coverage of white terrorists often include in depth analysis of their lives and personalities as if trying to ascertain where they went wrong; they are not terrorist "others," only "good boys" who have tragically strayed down the wrong path (Corbin, 2017). Legal proceedings are not immune to humanistic rhetoric about white terrorists either; the magistrate overseeing the prosecution of Dylann Roof, a white terrorist, confided: "[w]e have victims, nine of them. But we also have victims on the other side ... There are victims on this young man's side of the family" (Wash. Post, 2015). Furthermore, as terrorist attacks perpetrated by white attackers are perceived as "one-offs," white Christian men are not subject to the profiling heaped upon non-white Muslims (Corbin, 2017). This double standard of the application of the "terrorist" label 
is seen time and again in legal proceedings. Dylann Roof's killing of nine African-American worshippers at a church in Charleston County, South Carolina, is labeled a hate crime, despite the perpetrator having left a 2000-word manifesto claiming he wanted to start a race war and stating during an interview: "I had to do it because somebody had to do something ... Black people are killing white people every day on the street, and they are raping white women. What I did is so minuscule to what they're doing to white people every day all the time" (Norris, 2017; Corbin, 2017). Akayed Ullah, who is a non-white Muslim by comparison, was labeled a terrorist despite having killed only himself during a subway bus terminal bombing in New York (Norris, 2017).

This hesitancy to label white Christian violence as terrorism is endemic of a deeper, societal racism in which recognition or even mention of the problem is taboo, (DiAngelo, 2006, 2011). From a white perspective, whiteness is sensed as a kind of unbiased, universal baseline, devoid of a unique cultural perspective and instead representative of objective reality (McIntosh, 1988, DiAngelo, 2011). White people are never "white people," merely "people," and thus their experiences are representative of everyone's experiences; they are never members of a racialized group but merely individuals, completely separated from the racist implications of history or from the actions of other members of their racial group (DiAngelo, 2010). From that perspective, racism and privilege may be recognized as problems, but they are never "our prob- lem," only the unfortunate results of actions taken by other "bad white people" and thus outside of "our" sphere of control or concern (DiAngelo, 2010). On the other hand, people of color are never conceptualized as merely "people," they are inextricable from their racial context and inherently separate from the white experience (DiAngelo, 2011). This separation results in the concept of a deracialized (white) environment representing not a societal loss but a societal gain (Johnson \& Shapiro, 2003). This lends itself to a racialized interpretation of coded language for "good schools" or "good neighborhoods" to mean "white schools" or "white neighborhoods" (Johnson \& Shapiro, 2003). These deracialized "white spaces" are reflections of white people's self-conceptions as inherently deracialized individuals, conceptions so deeply held that any challenge to that viewpoint whether overt or implied threatens to shatter the veil of a deracialized existence, resulting in feelings of deep discomfort often remedied by a series of socially sanctioned counter measures to distance oneself from the source of the discomfort (DiAngelo, 2011). Vodde (2001) describes it succinctly: "If privilege is defined as a legitimization of one's entitlement to resources, it can also be defined as permission to escape or avoid any challenges to this entitlement."

Beyond a strictly racial sense, most Americans are shielded from familiarity with their own complicity in supporting foreign and economic policies which have driven the creation of the very terrorist threats that now plague the public conscience, aided by 
a one-sided and caricatured view of geopolitics made truth by decades of Hollywood revisionism (Boggs \& Pollard, 2006). The mundane grievances of Muslim extremists-"American geopolitical hegemony, a long history of military interventions in the Middle East and elsewhere, unwavering support for Israel, enforcement of a neoliberal globalization regimen"-are lost behind a smokescreen of religious fundamentalism that Hollywood and the media are only too eager to perpetuate (Boggs \& Pollard, 2006). This relates directly to the problems the US government (and others) have had in deriving a standard definition of terrorism-how to differentiate "their" terrorism, which is unacceptable and bad, from "our" terrorism, which is acceptable and necessary (Chomsky \& Achcar, 2009). Viewed through this lens, even the events of 9/11 lose their apocryphal significance and are instead merely a reaction to a state of events set in motion by Western imperialism (Baudrillard, 2002). Truly it is the case that "America has the power and resources to refuse self-reflection. More pointedly, it is a nation that has developed a tradition of being oblivious to self-reflection" (Sardar \& Davies, 2002).

The fault does not entirely lie with Hollywood and the media, however; these same caricatured and racist accounts are espoused by political figures. Newt Gingrich, former Speaker of the House, equated aid to families with dependent children or single mothers with the downfall of civilization (Gingrich, 1995). Political fear mongering has made a space in public discourse for hate, to stoke fears of "Islamization" and the characterization of minorities as politically irrelevant at best or scapegoats for society's problems at large at worst (Perry \& Scrivens, 2017; Fleras \& Elliott, 2002). Increasingly the agenda of Domestic RWE is reflected not only in mainstream political discourse, but in the platforms of RW political parties (Mallea, 2011; McDonald, 2011; Art, 2006, Berezin, 2009, Mudde, 2005). Indeed, much contemporary rhetoric concerning immigrants characterizes them as criminal, lazy or untrustworthy, inadvertently legitimizing Domestic RW extremist ideology which claims much the same (Dudek \& Jaschke, 1981, 1982, 1984; Ohlemacher, 1998; Stöss, 2007). Much of President Trump's popularity is at once both symptom and cause of this dualistic rhetoric, demonizing the immigrant terrorist "other" and mythologizing notions of white innocence and supremacy (Corbin, 2017). Frequent characterizations of immigrants as criminals or invaders, coupled with his notoriously delayed and tepid condemnations of Domestic RWE and even apparent defense of the movement during numerous events including the Charleston "Unite the Right" rally in 2017, in which he insisted that there are "very fine people on both sides," legitimize the bipolar narrative of the foreign, criminal and terrorist "other" versus white innocence, virtue and supremacy (Corbin, 2017).

Mark Potok, senior fellow at the Southern Poverty Law Center and editor of the New Report, expands on the problem: “Today's radical right leaders 
are having remarkable success in pushing fringe ideas-typically based on sheer fantasy or just plain racism -into the political mainstream. Their divisive propaganda, which is being embraced by opportunistic politicians and pundits and exploited for partisan gain, is doing real damage to our country" (PR Newswire, 2012). Radical RW narratives are increasingly finding their way into mainstream discourse through a process known as "information laundering" in which fictionalized narratives are disguised as legitimate research on controversial contemporary issues (PR Newswire, 2012; Klein, 2012). These false narratives are then filtered through the Internet via a series of search engines, political blogs, and social networks until they are eventually picked up by mainstream media, each successive step adding additional layers of legitimacy to the original story (PR Newswire, 2012; Klein, 2012). Examples include claims that then presidential candidate Barack Obama was not an American citizen; the theory that the United Nation's nonbinding environmental sustainability plan is in reality a plot for global domination; or that Muslims are trying to integrate Shariah law into the United States court system (PR Newswire, 2012; Klein, 2012). These fictionalized narratives are written in an academic tone and presented in a professional manner to add legitimacy to their claims (Borrowman, 1999). These include reputable sounding titles and research organizations, affiliations with reputable universities, citations of published works, academic credentials, professional looking formats, and links to real stories on mainstream news sites all of which serve to convince the reader that not only is the author rational, reasonable and intelligent, but that the website as a whole is a legitimate source of information (Borrowman, 1999; Klein, 2012). The QAnon movement is a novel example in which outlandish accusations of partisan conspiracy, child trafficking and demon worship posted anonymously to message boards online gain credence by claiming to have been authored by an individual with insider knowledge of the Trump administration.

The vast, interconnected nature of the Internet allows for a wider array of information to be accessed by any given researcher and a greater number of opinions to be presented (Klein, 2012). The unforeseen consequence is that the same pathways which lead to authentic information, such as Google or YouTube, also lead to hate sites or fictitious political narratives (Klein ,2012). After receiving enough attention, pundits of fictionalized narratives are invited into mainstream discourse, a prime example being representatives of the Family Research Council, an anti-gay propagandist group being invited onto various news networks like FOX and CNN 52 times in a single year (News Networks, 2011). A more contemporary example is Fox News' engagement with and defense of the QAnon movement following the Capitol attack (Peltz, 2021).

\section{Extremism and Media}

It is no secret that terrorists and media appear to be helplessly embroiled in a mutually beneficial relationship, 
nor have perceptions much changed in the last several decades as evidenced by Margaret Thatcher's famous 1985 comparison of the media to terrorism's oxygen (Lewis, 2005; Biernatzki, 2002; Weimann \& Winn, 1994; Nacos, 2007). Terrorists benefit from media coverage by gaining not only dissemination of their grievances on a massive scale, but also legitimacy in the eyes of their victims and sympathizers (Wilkinson, 1997; Weimann \& Winn, 1994). Media organizations stand to benefit from the boost in audience inherent in covering such a sensational event (Wilkinson, 1997). Furthermore, the dramatic and repetitive structure of the news cycle predisposes media organizations to cover terrorist incidents, a benefit further enjoyed by terrorist organizations (Nacos, 2007; Paletz \& Boiney, 1992). Technological advances in media dissemination and reach have likewise benefited the terrorist organizations they cover, serving to magnify the perceived support of organizations and reinforcing the legitimacy of more violent and "newsworthy" organizations over more benign and thus less "newsworthy" organizations (Rohner \& Frey, 2007; Tullock, 1974). The rise of Social Media and its increasing salience to other forms of mass media has further amplified the reach and news worthiness of terrorist organizations. In addition, the adoption or defense of RW extremist rhetoric by then President Trump and the Republican party at large has legitimized the movement on a massive scale (Stanley, 2021).

Terrorist organizations are generally opposed to mass media's preoc- cupation with democracy and concern for human life and rights; however, savvy organizations often include dedicated media arms tasked solely with influencing the messaging media organizations adopt to describe the organization (Wilkinson, 1997). There is recognized utility to be found in media reports describing motives, weapons, or tactics used in attacks for use by would be copycats (Larsson, 2014). Termed the "contagion effect," media's propensity not only to inform and motivate potential copycat attacks but also to educate them on previously effective or ineffective tactics, has resulted in the perception of mass media as involved in a destructive cycle, accomplices of the terrorists they cover (Weimann \& Winn, 1994; Paletz \& Boiney, 1992; Midlarsky, Crenshaw \& Yoshida, 1980; Jenkins, 1981; Weimann, 1983; Laquer, 1999; Scott, 2001). This problem is only exacerbated by Internet access, large audiences, and the speed of message dissemination afforded with social media (Ophir \& Weimann, 2012). While some have called for the regulation or censorship of media, other research has pointed out that the contagion effect is based on contested and irrelevant literature researching TV and violence, and that the majority of terrorist incidents never even receive coverage (Biernatzki, 2002; Perl, 1997; Picard, 1986; Weimann \& Winn, 1994; Norris et al., 2003).

Another view recognizes the issue of media's relationship with terrorism but places the onus of responsibility on the media organization itself for regulating what it reports (Wilkinson, 1997). Although it is recognized that 
terrorism is a communicative event and thus dependent upon media to disseminate its message, it falls upon the media to act as a facilitator to this communication and thus portray the terrorist organization and its acts in a responsible way (Norris et al., 2003). Responsible media organizations can banish the narrative that terrorists are downtrodden victims of oppression by portraying their wanton violence against innocent people in the name of political ideology (Wilkinson, 1997). More than merely amplifying acts of terrorism, media also sanitizes them and contains them within a given setting (Hoskins \& O'Loughlin, 2007). Media presents the context in which the public perceives acts of terrorism, not only juxtaposing legitimate and illegitimate violence but also tying a series of beliefs to that violence (Boyd, 2000; Jenkins, 2003).

However, the one-sided presentation of stories which "furnish consistent, predictable, simple, and powerful narratives that are embedded in the social construction of reality," predispose the media to government exploitation by ignoring larger geopolitical factors in favor of threats (Norris et al., 2003; Picard, 1991; Nacos et al., 2011). Uncritical representation of government narratives as fact prevent media from even conceiving of alternative viewpoints (Norris et al., 2003). This is especially true of coverage of terrorism in which media is dominated by official sources and tends to adhere to authoritative narratives of the event (Jenkins, 2003; DiMaggio, 2009; Paletz \& Vinson, 1992; Griffin, 2010; Thussu \& Freedman, 2003). When stories crit- ical of government are reported, they tend to differ from the official narrative in matters of degree and not substance, not questioning grand strategies or the justness of a war, but military tactics or shortfalls (DiMaggio, 2009; Lewis, 2008). In this way, media tends to act as a pundit of official policy and a cheerleader for war that uncritically accepts government conflations of military spending with security or support for the troops without ever considering an alternative (Carruthers, 2011; Lewis, 2008). In the event of a terrorist incident, the media propagates the government's own counter-terrorism message, granting legitimacy not to the terrorists but to the government and are thus indispensable in managing terrorist crises (Hammond, 2007; Mogensen, 2008). While these studies serve to increase understanding of mainstream perceptions of Domestic RWE and how it relates to mass communication, still others seek to define Domestic RWE as a unique phenomenon.

\section{Domestic Right-wing Extremist Ideology}

Domestic RW extremist ideology is a convoluted web of interrelated views espoused to varying degrees by different groups and individual actors. For the purposes of this study, the author will organize them by attributes of ideology and not by group, beginning with the most commonly held aspects of ideology before moving on to the more individualized. The most prevalent aspect of Domestic RW extremist ideology, one that is found in virtually every 
facet of the movement and is informed by Domestic RW extremist views on race, taxation, and government is the belief in conspiracy theories (Barkun, 2013). Ironically this prevalent facet of extremist ideology has frequently predisposed adherents to political manipulation and fear mongering (Berlet \& Lyons, 2010). Again, Donald Trump's presidency is a contemporary example of a political pundit utilizing conspiracy theories to manipulate their supporters and the media environment. The most comprehensive conspiracy theory is that of the New World Order (or Zionist Occupied Government) in which a shadowy cabal of nefarious actors ranging from liberals to communists to Jews are engaged in a centuries old conspiracy to wrest control of the world from legitimate governments to the detriment of the "white race" (Bjelopera, 2017; Crothers, 2003; Sharpe, 2000; Grumke, 2017; Pierce, 1997). The goal of this domination can be described in religious or sectarian terms, but always includes the mass subjugation of white people via a myriad of seemingly harmless vectors including the United Nations, human rights legislation, or immigration (Barkun, 1994; Pierce, 1997; Bjelopera, 2017; Crothers, 2003; Grumke, 2017; Barkun, 1995). The central ideology of the QAnon movement is a variation of this popular conspiracy theory. Adherents to this and other conspiracy theories seek out and invariably find confirmative evidence supporting their theory while ignoring or minimizing any contradictory evidence or alternative hypotheses, creating a feedback loop of falsely positivistic pseudo-sci- entific theory (Popper, 1966, 1968; Bittner, 1963).

Often described as the "glue" which holds right-wing extremist ideology together, anti-Semitism has played a role in the ideology for centuries (Lipset, 1987; Klein, 2010). Jews, in the Domestic RW extremist ideological sense, are often inextricably linked with prominent conspiracy theories that play central roles in the motivating ideology of many Domestic RW extremist groups (Kaplan, 1995; Brannan, 2006). Domestic RW extremist views regarding Jews are full of religious rhetoric, often describing them as the timeless enemies of Christianity, or even descendants of the devil who have supplanted Aryans as God's chosen people (Kaplan, 1995; Brannan, 2006). While Jews are the central enemies in most Domestic RW extremist ideology, many researchers agree that there is nothing specific about Jewish people or ancestry which sets them apart for demonization and if the ideology did not seize on them specifically for condemnation, another group would quickly take their place as the prime villain, an assertion often supported by conspiracist references to a United Nations controlled New World Order (Lipset, 1987; Langauir, 1990; Kaplan, 1995; Sartre, 1948).

Both conspiracy theorist and anti-Semitic beliefs contain elements of racial superiority, the assertion that all races of people exist in a rigid hierarchy with the "white race" immutably placed at the top (Feagin \& Feagin, 1993; Fortney, 1977; Haller, 1971). This notion of "white supremacy" is often reinforced 
with historic or naturalistic rhetoric and borrows terminology from traditional Norse religious beliefs (Flowere, 1981). Condemnation of racial mixing is a central tenet of white supremacist belief and is linked to every form of social malaise or physical illness (Aho, 1990; Shanks-Meille \& Dobratz, 1991). Those who miscegenate or who do not support this white supremacist ideology are labeled "race traitors" and considered by adherents to be worse than non-whites (Aho, 1990; Fielding, 1981). Non-whites are invariably cast as the "other," dehumanized, compared to animals, characterized as possessing a myriad of "uncivilized" qualities and referred to in unsympathetic, threatening language justifying violent reaction (Perry \& Scrivens, 2017; Sharpe, 2000).

The justification of violence against perceived enemies of white people is a common theme in Domestic RW extremist discourse, commonly framed in terms of Manichean struggles between good and evil in which all tactics are justified (Wilkinson, 1997). Religious justifications posit the unique humanity of the white race, concluding that non-whites are not human at all and thus God neither hears their prayers nor cares about their well-being (Sharpe, 2000). In Domestic RW extremist ideology, the "white race" is constantly under siege from every direction, strangled by liberal economic policies, polluted by interracial marriage, and living in a world shaped by anti-white conspiracies (Sprinzak, 1991; Bjelopera, 2017; Bell, 2002; Lipset, 1959; Finlay, 2007; Grumke, 2017; Languair, 1990). If the enemy is inhuman, if non-violent means are ineffective and if the motivations for action are undeniably just, then any degree of action no matter how violent is inevitably justified (Saucier et al., 2009). In periods of social change or perceived challenge of white hegemony, these perceptions are likely to increase under the increasing pressures of horizontal or vertical competition (Lipset, 1981; Buzan et al., 1998).

Domestic RW extremist discourse often engages in millenarianism, the assertion that the apocalypse is imminent, or catastrophizing, the idea that terrible disasters have happened, will happen, or are taking place right now (Saucier, 2009). These ideas are often cast in religious terms in whatever form is familiar to their adherent. Christian milennials may envision the coming of Christ preceded by years of tribulations, while sectarian followers envision an imminent racial holy war, expressed in shorthand via the acronym "RAHOWA" (Aho, 1990; White, 1989; Kaplan, 1995; Bjelopera, 2017; O'Leary, 1994; Intelligence Report, 1998; Doskoch, 1995). While millenarian assertions are clad in religious phraseology, Landes (2006) asserts that they invariably represent political aspirations, "to bring about a transformation of the social, and therefore the political, universe." The flip side of this rhetoric is the utopianization of a deracialized world in which white hegemony is not only global, but everlasting (Saucier, 2009).

In support of explicit propaganda, the mere re-framing of issues many Americans sympathize with can 
have a drastic impact on public opinion (Saucier, 2009). Historical revisionism is a prime example of this and is used in right-wing extremist discourse to curry sympathy and inflame outrage. America's history of African-American slavery and oppression are flipped, portraying white Americans as the downtrodden victims of an anti-white liberal establishment (Finlay, 2007). Aryans displace Jews as God's chosen people, claiming Jewish ancestry, polluted with non-white Khazak blood or worse, has supplanted their God-given place (Hoffman, 2006; Aho, 1990; White, 1989). Romantic rhetoric of an independent, economically laissez faire "Old West" is used to prop up anti-regulatory policies in historically the most subsidized region of the United States (White, 1997; Merrill, 1999). Revisionist rhetoric wraps itself in an idealized, ultra-nationalistic version of history in which white America equates the nation-and the nation can never be wrong. Themes from American revolutionary history are romanticized and used to legitimate modern anti-government militias and violent action (Gage, 2011). Domestic RW extremist ideology goes on and on, re-framing current realities, re-imagining historical events and reviving lost racist ideals; however, the method by which the movement disseminates the message is also an effective contributor to its salience.

\section{Domestic Right-wing Extremist Organization}

Like terrorism, the primary function of RWE is not to impose its beliefs through violence but to spread its ideology; violence is merely a vector of communication (Schmid, 2005). For the same reason Domestic RW extremist ideology is presented in graphic, offensive forms to capture the viewer's attention and instill a reaction, mobilizing an apathetic public (Aho, 1990; Deutsch, 1961). The Internet is a powerful tool for the spread of RW extremist ideology, allowing the movement to sidestep traditional media gatekeepers to disseminate its message (Nacos, 2006). However, the utility of the Internet and by extension, social media goes far beyond merely spreading propaganda, it is in essence a one-stop shop where extremist organizers can communicate with other individuals, plan attacks, seek out and receive funding, gather information to be used in counter-messaging or operational planning, or radicalize new actors and teach them how to carry out attacks (Nacos, 2006; Klein, 2012; Erbschloe, 2019; Dean et al., 2012; Neumann, 2009). The anonymity afforded users via the Internet allows them the freedom to engage in actions normally deemed unacceptable, to self-select into media congruent with their own beliefs and to congregate with like-minded others in online extremist communities (Dean et al., 2012; Neumann, 2009; Chan et al., 2013; Byrne, 2007; Daniels, 2009; Simi \& Futrell, 2009; Blee, 2002; Futrell et al., 2006; Gerstenfeld, 2003; Levin, 2002; Reid \& Chen, 2007). Internet access can be especially important for lone wolf actors to develop their own radical identities, especially in the later stages of violent radicalization (Ducol et al., 2016).

The concept of inclusiveness is 
important in understanding radicalization. Many would be extremists experience feelings of social isolation, low self-esteem, or disillusionment that cause them to actively seek out communities of like-minded individuals online (Seib \& Janbek, 2011; Decker \& Pyrooz, 2015; Moghaddam, 2008; Gewirtz \& Baer, 1958; de Roy van Zuijdewijn \& Bakker, 2016; Kailemia, 2016; Roger et al., 2007). These groups can offer membership in a family of peers, privileged information on "the way the world really is" and the chance to craft the user's own unique identity by contributing to an ideal greater than themselves (Roger, et al., 2007; Althusser, 1970; Perry \& Scrivens, 2017; Moghaddam, 2008; Koehler, 2014). Group members begin to see the group as their family and strive to advance within it, their goals mesh with those of the group, and the pressure to conform even against social taboos is immense (Berger, 1967; Althusser, 1970; Asch, 1958; Milgram, 1974). Extremist websites go out of their way to create this sense of family by catering to every social need of the individual (stormfront.org). There are dating services, forums on fitness and literature, even sections of the website dedicated to children (stormfront.org).

International cooperation and funding are growing aspects of Domestic RW extremist organization. Websites espouse international fraternities with like-minded individuals in other countries (Grumke, 2017). Hate music is a unique approach to both international reach and funding. Hate music is a powerful recruitment tool, especially effective at radicalizing younger listen- ers by creating a cohesive folklore and validating feelings of frustration with calls to violence (Cotter, 1999; Preston \& Schwirtz, 2012). Annual hate music festivals are held to raise money for the movement and to offer a chance for geographically distanced sympathizers to meet and socialize away from society's taboos (Blee, 2010; Futrell \& Simi, 2012; Simi \& Futrell, 2010). One prominent hate music record label reported $\$ 1$ million in annual sales (Heim, 2012). Additionally, legitimate websites like the Christian crowd funding site GiveSendGo.com have recently reported massive increases in profits as supporters of domestic RW movements have flocked to their sites to donate money to a variety of causes, from the legal defense funds of terrorists to equipping groups such as the Proud Boys with tactical equipment (de Puy Kamp \& Glover, 2021).

Considered spatially, the domestic RW extremist movement resembles an extremely loose network populated with myriad nodes interconnected with extremely weak, even latent ties (Latour, 1996). Far from being a weakness, this diffuse organization with weak ties makes the network incredibly resilient and effective at dissemination with latent ties activating or deactivating as necessary (Latour, 1996; Mayntz, 2004). Central nodes are ideological artifacts, key works of domestic RW extremist literature or ideology that remain static online or in print for decades, radicalizing sympathizers who stumble upon them and inspiring future generations of both activists and ideological authors alike (Keatinge, 2019; Kaplan, 1995; Grumke, 2017; Nacos, 2006; Skoll, 2006; 
Bjelopera, 2017). This organization lends itself to the leaderless resistance model advocated for RW extremist action in the United States in the 1980s by a Ku Klux Klan Grand Dragon named Louis Beam (Bjelopera, 2017; Perry \& Scrivens, 2017; Leader \& Probst, 2003; Joosse, 2007). This two-part model benefits from First Amendment protections to allow creators of domestic RW extremist ideology to disseminate propaganda and calls to action in the public sphere while avoiding any connection with terrorists (Bjelopera, 2012, 2017). Consumers of the ideology gain motivation to engage in illegal activity without any direction or participation from their above-ground counterparts (Bjelopera, 2012, 2017). The threat is amplified by the widespread and decentralized nature of ideological consumers across the country (Sullivan, 2012).

\section{Research Methodology}

1 This research uses a mixed-methods design to compare the number of deaths resulting from domestic RW extremist attacks in the United States from 2000 to 2020 with aspects of the ideology espoused by the attackers. Attack data compiled by the GTD, a project by the National Consortium for the Study of Terrorism and Responses to Terrorism (START), was compared to primary source documents of attackers' ideology gathered from news media archives vetted by the GTD. Quantitative data was gathered about the number of deaths from the GTD directly. Qualitative data about the aspects of ideology espoused by the attackers was gathered from primary source materials referenced in news media archives that have in turn been vetted and referenced in the GTD. This ideological data underwent an initial analysis using a grounded theory approach in order to codify a standard lexicon of ideological categories before being compared to the number of deaths using Pearson's correlation coefficient with a 0.05 degree of significance. Correlations identified in this manner represent potential theoretical relationships and avenues of future research and CVE legislation.

\section{Research Framework}

The Grounded Theory approach, developed by Glaser and Strauss (1967), seeks to develop new theories unaffected by other theoretical perspectives that are grounded in the data they analyze (hence the name). The authors posit that development of theory is processual-it is ever changing and adapts to new information as it is targeted for collection and analyzed. Furthermore, theory can nearly develop itself by comparing categories with sets of quantitative data as any correlations between these types of data clearly identify new associations to be conceptualized and analyzed (Glaser \& Strauss, 1967). In short, the researcher, "induces a theory simply from the general relationships [s] he has found" (Glaser \& Strauss, 1967). In the same fashion, the ideological aspects of the attacker, identified using grounded theory analysis and representing the independent variable, were compared to the number of victims in an attack, 
representing the dependent variable. Any correlation between the number of victims and the attacker's ideological aspects proves the hypothesis, while a lack of correlation disproves it, represented by the following hypothesis: the attackers' ideology correlates with the number of deaths resulting from domestic RW extremist attacks in the United States between 2000 and 2020.

\section{Data Collection}

Quantitative attack data were gathered directly from the GTD while qualitative ideological data were gathered from primary sources included in news archives vetted and referenced by the GTD. The sample consists of all attacks in the United States from 2000 to 2020 identified as domestic RW extremist or which included aspects of domestic RW extremist ideology analyzed by the GTD. Attacks that are not identified as domestic RW extremist or did not include aspects of domestic RW extremist ideology were not included. The GTD draws its data from a global supply of open-source news articles, which undergo a series of increasingly stringent analyses to determine inclusivity. The first level of analysis is entirely automated and seeks to collect and organize relevant articles from news organizations from over 160 countries using a set of keyword filters (Miller et al., 2019). Translated articles are acquired from the Open-Source Enterprise (www. opensource.gov). The second level uses natural language processing to further refine the included articles, remove duplicates, and identify those that are likely to be relevant (Miller et al., 2019). GTD reviewers analyze each article included in this list manually to determine if the unique inclusion criteria of the GTD are satisfied (Miller et al., 2019). Those that are included are then coded for inclusion in the GTD (Miller et al., 2019). GTD researchers recognize that source validity is imperative to an accurate database, thus sources are regularly analyzed for validity (Miller et al., 2019). Sources which “...are independent (free of influence from the government, political perpetrators, or corporations), ... routinely report externally verifiable content, ... are primary rather than secondary," are considered vetted and prioritized over lower quality sources (Miller et al., 2019). Data reported only by, "distinctly biased or unreliable sources," are not included (Miller et al., 2019). Sources of qualitative data are gathered from the GTD's list of vetted news archives. Primary sources are then identified in the archive and chosen based on their inclusion of ideological information espoused by the perpetrator of a specific violent event.

\section{Results}

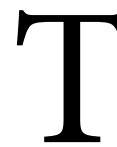

The analysis detailed in the Methodology section identified 49 aspects of domestic RW extremist ideology present in the 76 domestic RW extremist attacks analyzed (see Appen$\operatorname{dix}$ A). Any attack that was not classified as domestic RW extremist in origin, but which included aspects of domestic RW extremist ideology, was included in the analysis. Every attack resulting in one or 
more deaths was analyzed as well as 29 out of the 316 recorded attacks which resulted in zero deaths. Sampling continued until theoretical saturation was reached, yielding data for 29 attacks which resulted in zero deaths, 15 attacks which resulted in one death each, 11 attacks which resulted in two deaths each, seven attacks which resulted in three deaths each, three attacks which resulted in four deaths each, two attacks which resulted in five deaths each, one attack which resulted in six deaths, two attacks which resulted in seven deaths each, one attack which resulted in nine deaths, two attacks which resulted in 10 deaths each, one attack which resulted in 11 deaths, one attack which resulted in 17 deaths and one attack which resulted in 59 deaths (see Table 1).

Table 1: Number of deaths resulting from domestic RWE attacks in the US from 2000 to 2020 and corresponding minimum sample size and degrees of freedom

\begin{tabular}{|l|c|c|c|c|c|c|c|c|c|c|c|c|c|}
\hline \# of Deaths & 0 & 1 & 2 & 3 & 4 & 5 & 6 & 7 & 9 & 10 & 11 & 17 & 59 \\
\hline \# of Attacks & 29 & 15 & 11 & 7 & 3 & 2 & 1 & 2 & 1 & 2 & 1 & 1 & 1 \\
\hline $\begin{array}{l}\text { Analysis Group } \\
\text { (\# of Attacks) }\end{array}$ & $7+$ & $7+$ & $7+$ & $7+$ & $3+$ & $2+$ & $1+$ & $2+$ & $1+$ & $2+$ & $1+$ & $1+$ & $1+$ \\
\hline $\begin{array}{l}\text { Degrees of } \\
\text { Freedom }\end{array}$ & 3 & 3 & 3 & 3 & 4 & 7 & 12 & 7 & 12 & 7 & 12 & 12 & 12 \\
\hline
\end{tabular}

When analyzed together, numerous aspects of ideology were found to correlate with the number of deaths; however, the cases with the highest number of deaths numbered so few that the degree of correlation was driven completely by the presence or absence of that aspect of ideology in the few attacks with the highest deaths, regardless of its presence or absence in attacks with fewer deaths. To provide a more meaningful analysis, the researcher excluded any number of deaths that were not associated with at least seven attacks, resulting in data for attacks resulting in between zero and three deaths. Data excluded this way is included in the discussion of the findings. This ensures the degree of correlation for each identified aspect of ideology is more representative of the sample as a whole and not merely a reflection of their inclusion or exclusion in the few attacks associated with the highest number of deaths.

Of the $n=62$ attacks with an occurrence rate of at least seven attacks (resulting in between zero and three deaths per attack), "attacker justified violence" was the only aspect of domestic RW extremist ideology found to correlate: $r(3)=0.9750, P=0.0250$ (see Figure 1).

Correspondingly the hypothesis detailed in the Introduction is proven correct: there is a correlation between at least one aspect of domestic RW extremist ideology and the number of deaths resulting from domestic RW extremist attacks in the United States between 2000 and 2020. It is possible that as many as eight other aspects of 
Percentage of cases associated with 'attacker justified violence'

 compared to number of deaths with a minimum sample size of 7 .

percentage of attacks associated with ideology

Figure 1. Percentage of cases associated with 'attacker justified violence' compared to number of deaths with a minimum sample size of 7

Percentage of cases associated with "attacker justified violence"' compared to number of deaths with a minimum sample size of 3 .
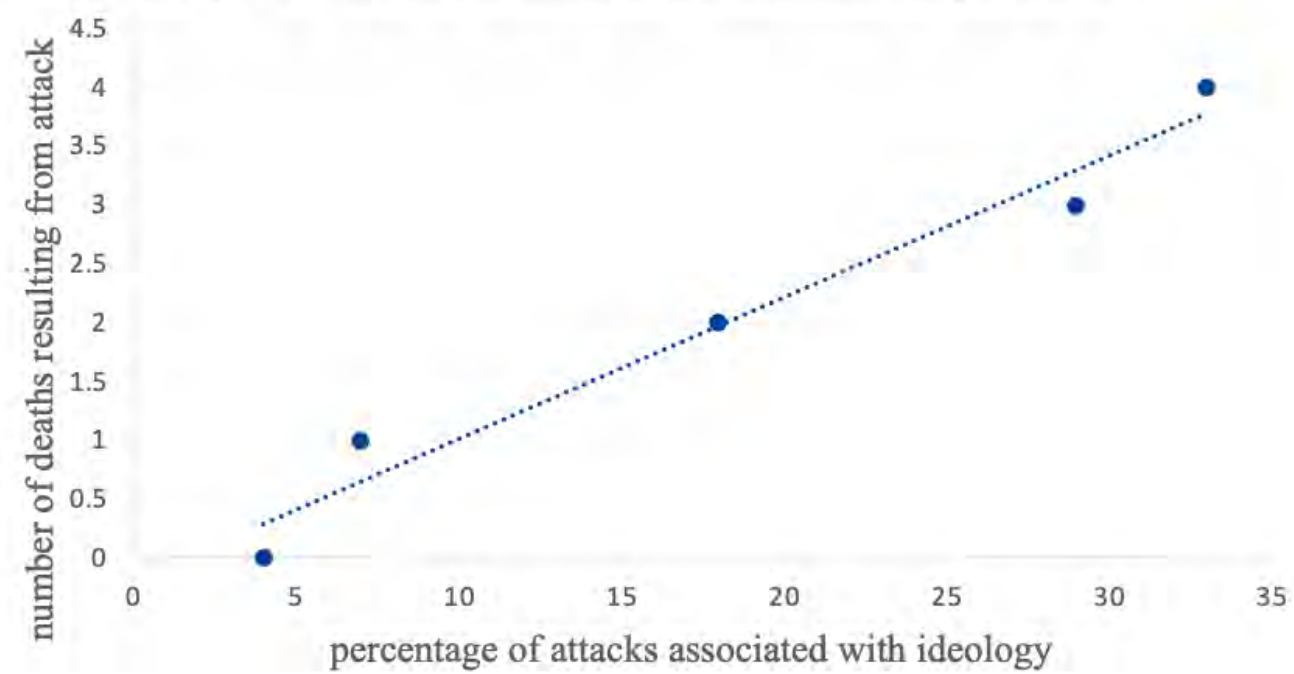

Figure 2. Percentage of cases associated with "attacker justified violence" compared to number of deaths with a minimum sample size of 3 
Percentage of cases associated with "attacker glorified their own death" compared to number of deaths with a minimum sample size of 3 .

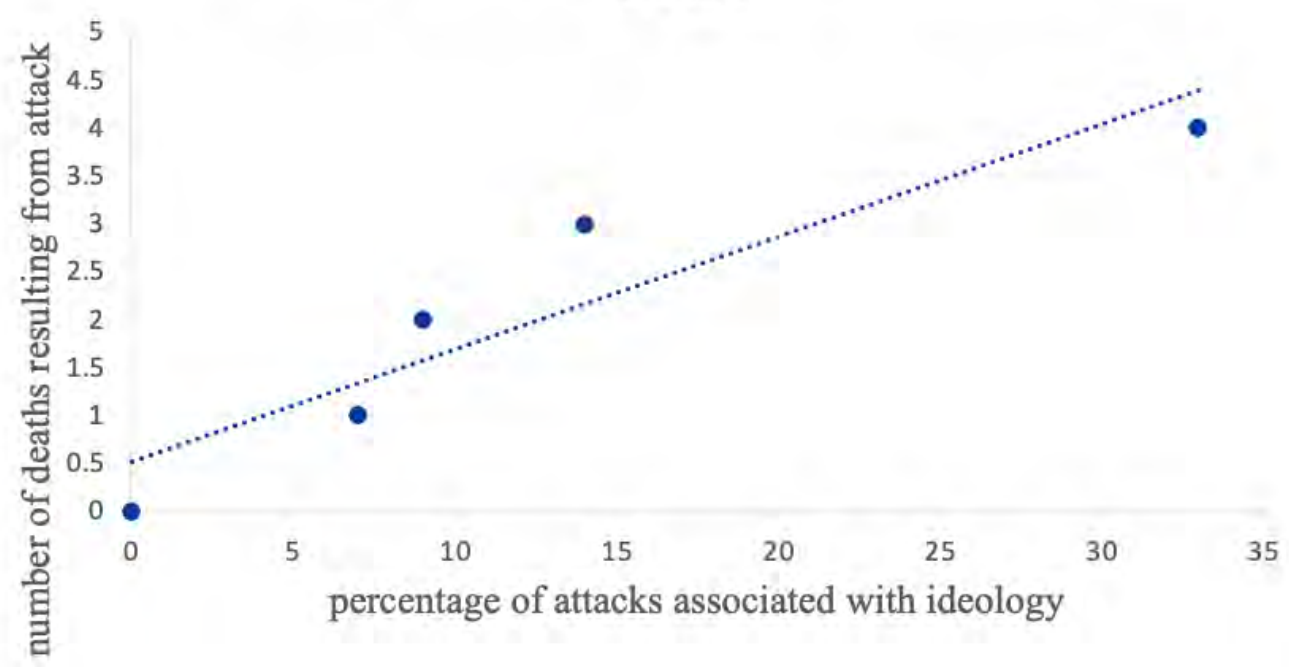

Figure 3. Percentage of cases associated with "attacker glorified their own death" compared to number of deaths with a minimum sample size of 3

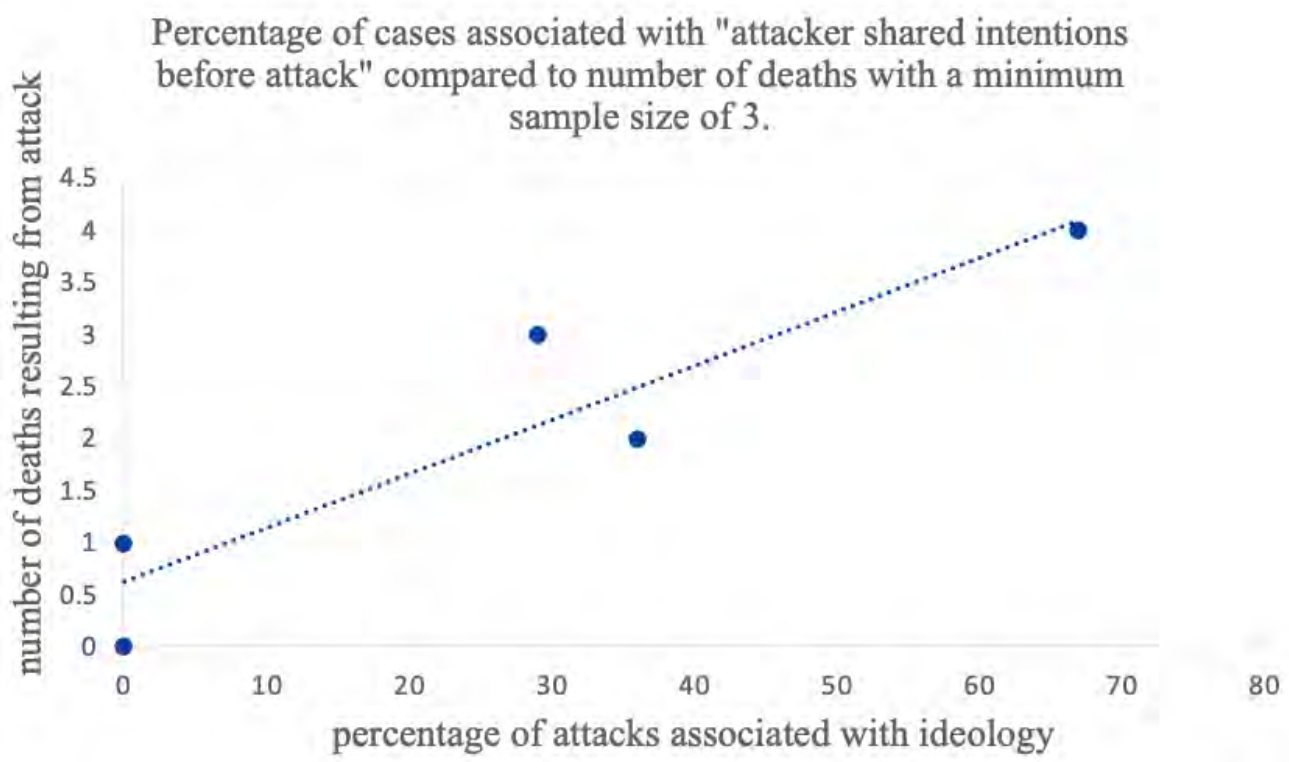

Figure 4. Percentage of cases associated with "attacker shared intentions before attack" compared to number of deaths with a minimum sample size of 3 
domestic RW extremist ideology also correlate; however, additional data is necessary to confirm this. Among surveyed attacks, the "attacker justified violence" aspect of ideology was described by attackers in terms detailing past violence (or perceived violence) committed against the attacker themselves, or against an ethnic or social group to which the attacker belongs, thus justifying their own violent actions in retaliation. Frequently, the attacker cited the high number of deaths within their own ethnic group perpetrated by members outside of their ethnic group, although other complaints existed including attacks against themselves or their ethnic group by the government, members of other social groups or members of other political affiliations. In many cases these complaints appear to be wholly contrived, while others reflect documented violence against an ethnic group or recorded legal grievance. The correlation between deaths and the percent of attacks adhering to an "attacker justified violence" ideology suggests that the greater the degree an attacker feels they or a group to which they belong has been harmed physically, socially or politically, the greater the degree of violence they feel justified or even compelled to commit in return. Whether the grievance the attacker holds is based in reality or merely a matter of their own perception plays little part in their feeling of justification. Indeed, the variation among issues due to which the attacker feels justified to commit violence which range from social ostracization to imagined or legitimate violence against their own ethnic group to their own peaceful and legal intentions suggests that what constitutes justification to commit violence is more driven by the attacker's own perceptions than by any measurable degree of injustice.

Analyzing the number of deaths with fewer than seven associated attacks reveals that "attacker justified violence" remains significant for all deaths associated with at least three attacks as well as all deaths associated with at least two attacks. Only when analyzing all deaths associated with at least one attack does "attacker justified violence" stop being significant. The fact that this aspect of ideology remains significant throughout the various occurrence rates surveyed supports the finding that "attacker justified violence" correlates with the number of deaths resulting from domestic RW extremist attacks.

Aspects of ideology found to correlate with all deaths associated with at least three attacks are: "attacker justified violence": $r(4)=0.9826, P=0.0028$ (see Figure 2), "attacker glorified their own death": $r(4)=0.9262, P=0.0238$ (see Figure 3), and "attacker shared their intentions before the attack": $r(4)=0.9197$, $P=0.0270$ (see Figure 4).

"Attacker glorified their own death" describes how an attacker views their own death in glorious or righteous terms. Attackers fitting this description viewed their attacks as vectors leading to their own death and cited that certainty as a reason for carrying out the attack. Whether the attacker sought to die by suicide or as a result of action by another party such as law enforce- 
ment did not affect their inclusion in this group. The correlation between this ideology and the number of deaths suggests a variation in the goal the attacker sought to achieve by carrying out an attack. Seeking to kill a small number of people and survive suggests the attacker is more concerned with their own life than with whatever result they hope to achieve through their violence, whereas an attacker planning to kill a large number of people appears to care relatively little about their own life compared to the goal they hope to achieve through their attack.

To be included in the "attacker shared intentions before the attack" classification, an attacker had to share their intentions to carry out a violent attack on a public forum before the attack was committed. In all cases, the intentions were published online either on social media or a website curated by the attacker, and in most cases, their intentions were originally published weeks or months before the attack took place. The method of publication, however, ensured that only people familiar with the attacker or with similar viewpoints or interests as the attacker ever saw these messages before the attack was carried out. In most cases, the messages were written like manifestos, detailing their grievances and actively trying to convince the reader of the justification of their actions. The correlation between this ideology and the number of deaths suggests either that the attacker's first choice was not to carry out an attack but to achieve their goals through threats, or that the attacker hoped to be caught before their attack could be carried out. If an attacker believed that the only way to alleviate their grievance was through carrying out an attack, why would they risk being discovered by law enforcement before their attack could be carried out merely to write about their intentions online.

Analyzing the number of deaths associated with at least two attacks reveals that the "attacker justified violence" aspect of ideology is still significant: $r(7)=0.766, P=0.0267$ (see Figure $5)$. Two other aspects of ideology are found to correlate with the number of deaths: "attacker was proud of attack": $r(7)=0.7979, P=0.0176$ (see Figure 6) and "attacker was socially isolated": $r(7)=0.8595, P=0.0062$ (see Figure 7).

The "attacker is proud of attack" aspect of ideology refers to how an attacker describes their own attack. To be included in this ideology, an attacker must have expressed their intention to become famous or to gain notoriety among a subset of society as a result of carrying out their attack. The majority of attackers within this subset sought to gain notoriety specifically among a small section of society, namely other adherents to their extremist ideology. In every case, the attacker referenced previous attacks, actors or goals shared by adherents to their extremist ideology and sought to either replicate those attacks, pay tribute to those actors or serve the same goals by carrying out their attack. Inclusion in this ideology suggests that an attacker not only was a member of a larger extremist community, but also held the tenants of that extremist ideology to such high esteem as 
Percentage of cases associated with "attacker justified violence" compared to number of deaths with a minimum sample size of 2 .

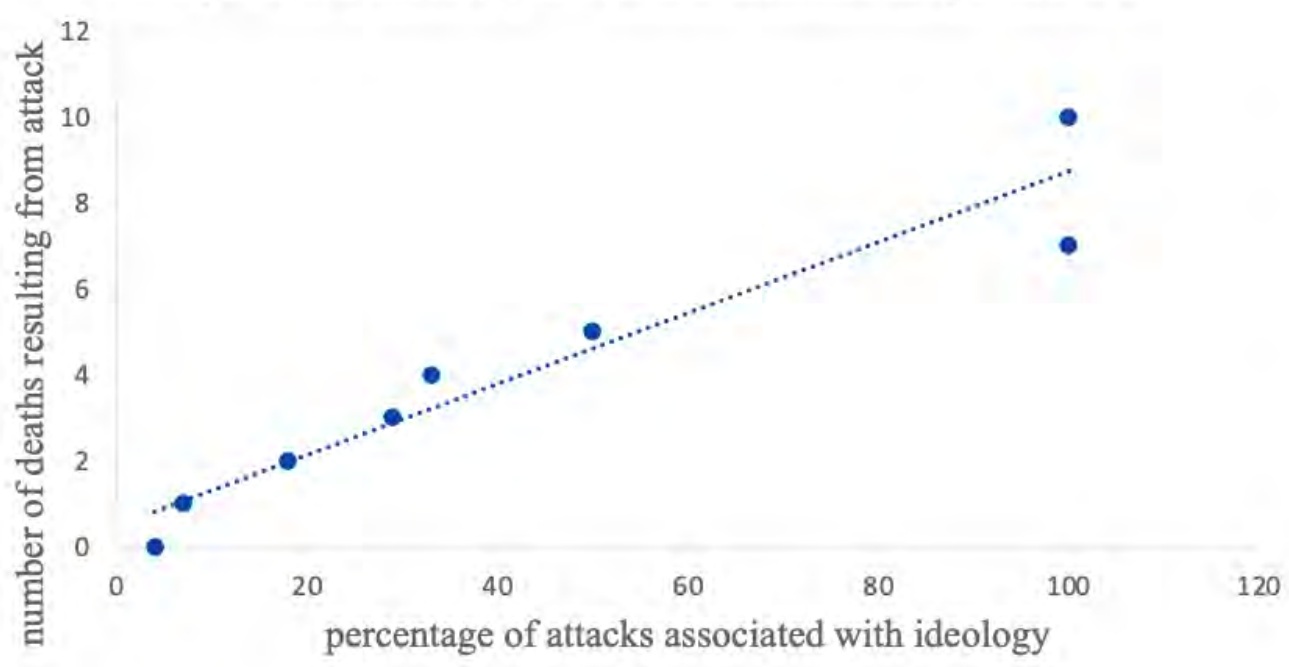

Figure 5. Percentage of cases associated with "attacker justified violence" compared to number of deaths with a minimum sample size of 2

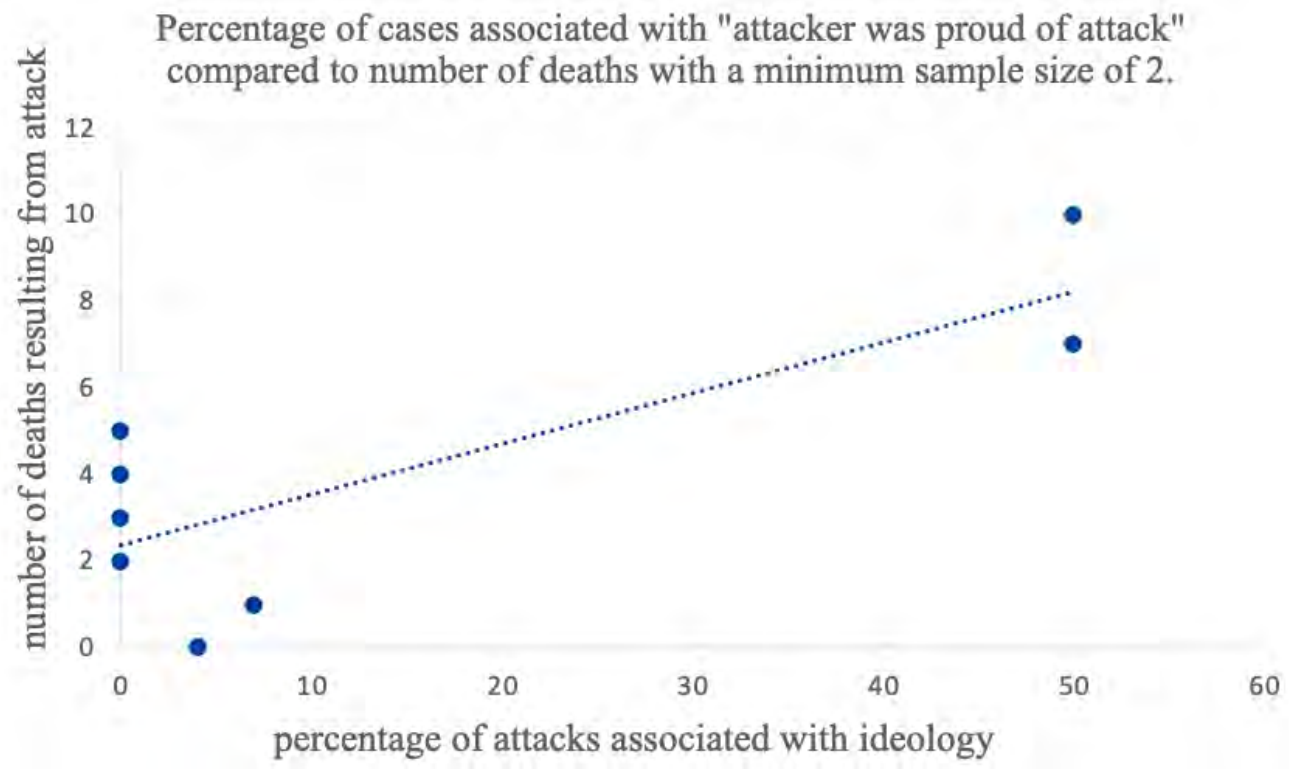

Figure 6. Percentage of cases associated with "attacker was proud of attack" compared to number of deaths with a minimum sample size of 2 


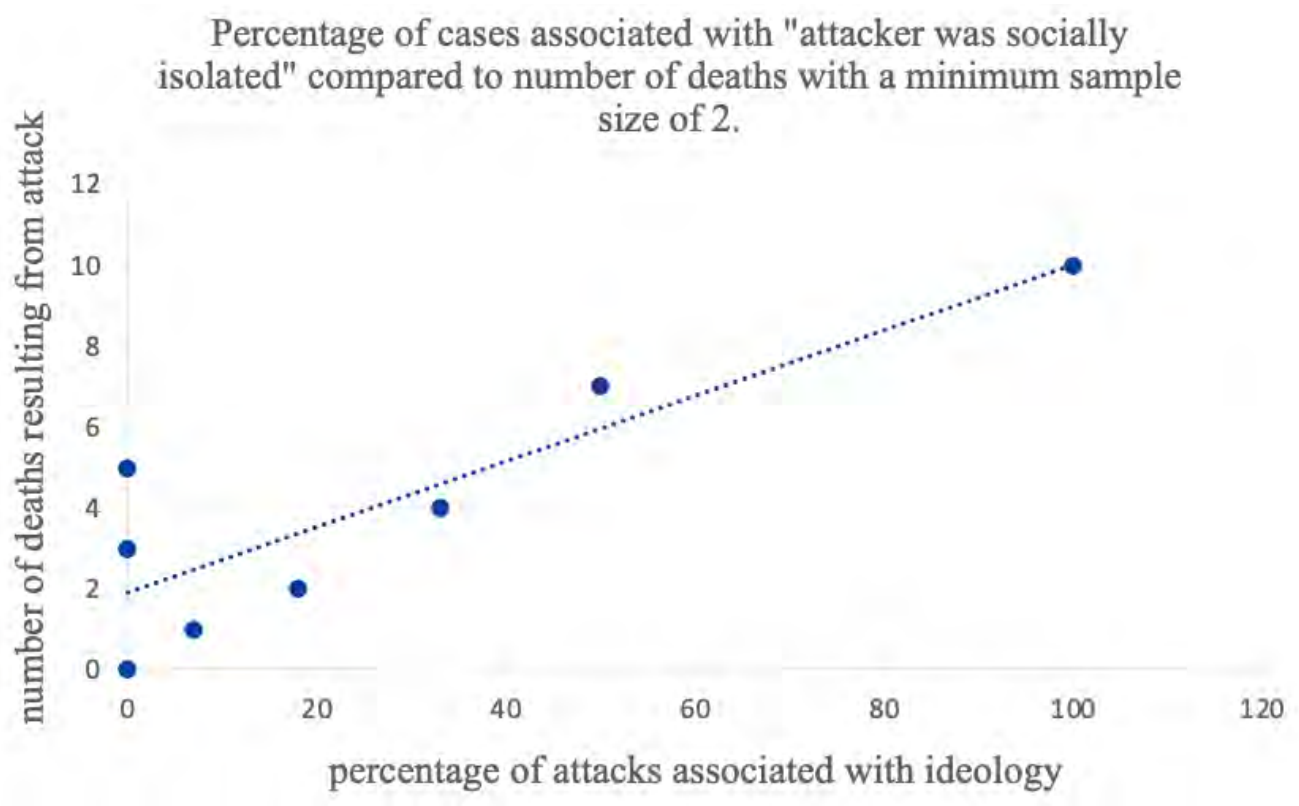

Figure 7. Percentage of cases associated with "attacker was socially isolated" compared to number of deaths with a minimum sample size of 2

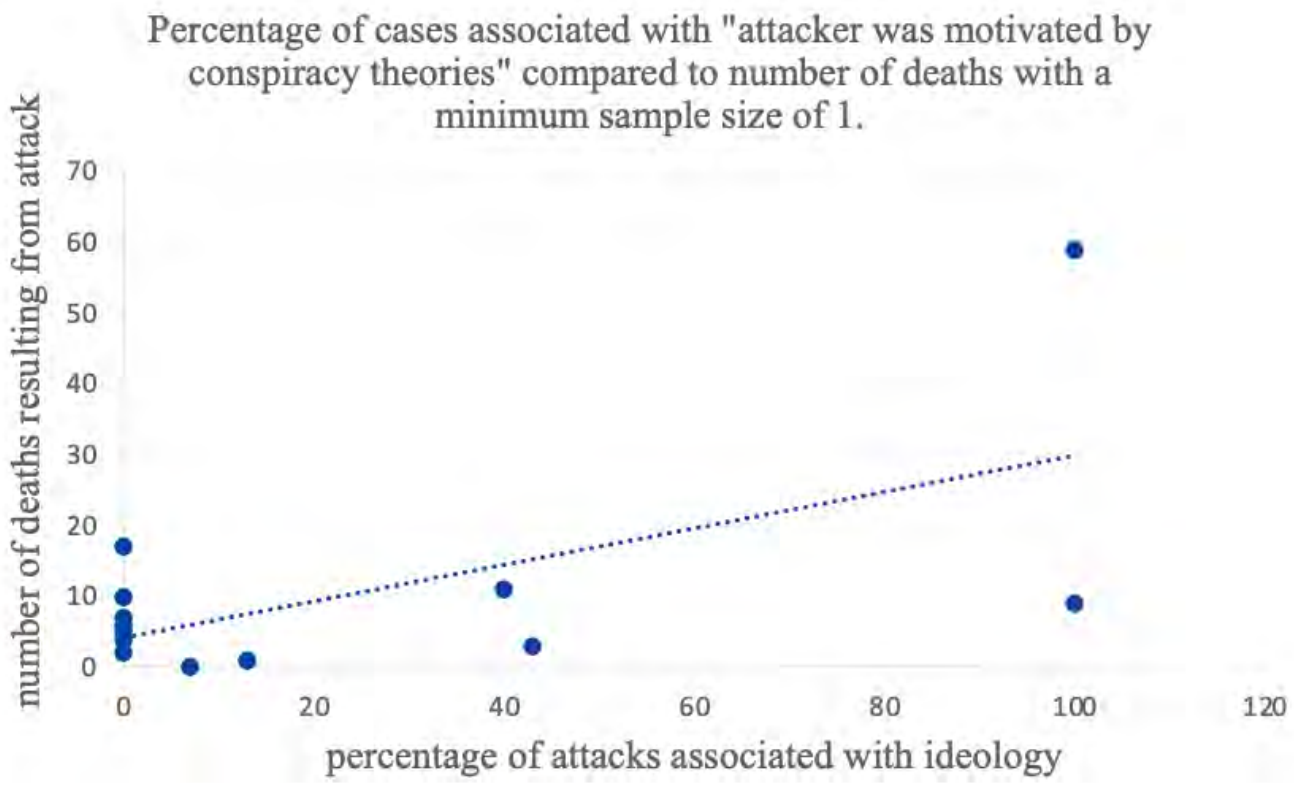

Figure 8. Percentage of cases associated with "attacker was motivated by conspiracy theories" compared to number of deaths with a minimum sample size of 1 
to be motivated to carry out an attack in pursuit of them. This data suggests that the greater the level of violence of an extremist attack, the more convinced the attacker must be that this course of action is not only the correct course to take, but in doing so they will be gaining the notoriety they have recognized in others who have committed similar acts.

To belong to the "attacker was socially isolated" aspect of ideology an attacker must have expressed their own experiences of social isolation as a motivator for carrying out their attack. The majority of these attackers had no significant contact with any group of people, even other adherents of extremist ideology. In every case, their sense of social isolation and either inability or unwillingness to belong to any social group was a major contributor to their decision to carry out an attack. In many of the attacks it was the primary motivating force behind the attack, although a significant number of attacks were driven primarily by another aspect of ideology. This correlation suggests that the presence of social networks may play a role in moderating potential extremists. The lack of such networks may enable a cycle of self-radicalization that results in extremist violence.

When analyzing all deaths caused by domestic RW extremist attacks regardless of the number of attacks associated with each number of deaths, the data shifts further. The "attacker justified violence" aspect of ideology is no longer significant in this bracket, instead "attacker is motivated by conspiracy theories": $r(12)=0.6212$, $P=0.0235$ (see Figure 8); "attacker was motivated by a political or financial grievance": $\quad r(12)=0.808, \quad P=0.0008$ (see Figure 9); "attacker glorified past domestic RW extremist attacks": $r(12)=0.7211, P=0.0054$ (see Figure 10); and "attacker believed the government is illegitimate": $r(12)=0.6237, P=0.0227$ (see Figure 11) are significant.

Inclusion in the "attacker was motivated by conspiracy theories" aspect of ideology required the attacker to reference a motivation leading to their attack which was not based in fact. The entirety of the attackers sampled referenced conspiracy theories related either to the National or Global government or the Jewish religion and ethnicity. The majority of attackers claimed that modern governments and social institutions are secretly run by a covert Jewish organization spanning the globe, some even claimed that the Holocaust was a fabrication in collaboration with the political left to achieve the aims of this group. The QAnon movement adheres to a variation of this popular conspiracy theory, but was not included in this statistical analysis as no attacks associated with that movement have yet been analyzed and included in the GTD. The remainder of attackers surveyed claimed that the United States government was illegitimate and involved in various schemes to defraud the American people ranging from illegal taxation to immigration plots to genocide instigated by the Federal Emergency Management Administration (FEMA). Some conspiracy theories combined the two, claiming liberal politicians are 
Percentage of cases associated with "attacker was motivated by a political or financial grievance" compared to number of deaths with a minimum sample size of 1 .

70

60

50

40

30

20

20
0

0

\section{0}

40

60

80

100

120

percentage of attacks associated with ideology

Figure 9. Percentage of cases associated with "attacker was motivated by a political or financial grievance" compared to number of deaths with a minimum sample size of 1

Percentage of cases associated with "attacker glorified past RW extremist attacks" compared to number of deaths with a minimum

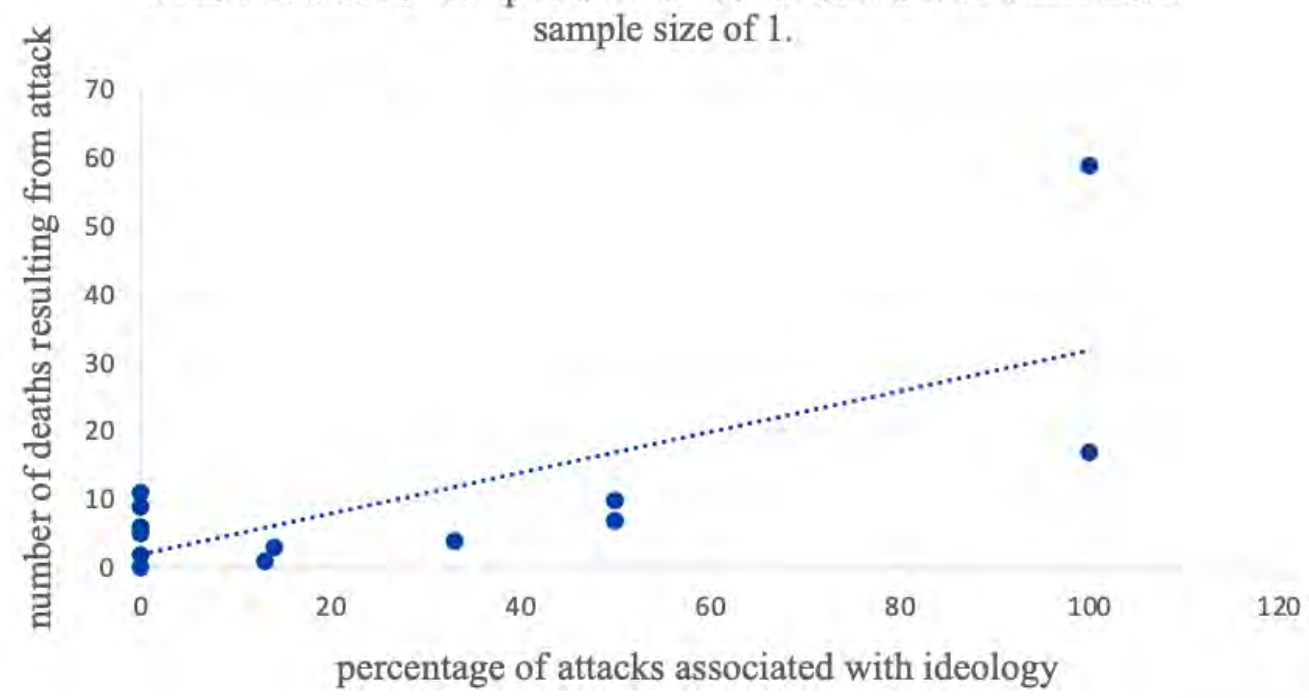

Figure 10. Percentage of cases associated with "attacker glorified past RW extremist attacks" compared to number of deaths with a minimum sample size of 1 


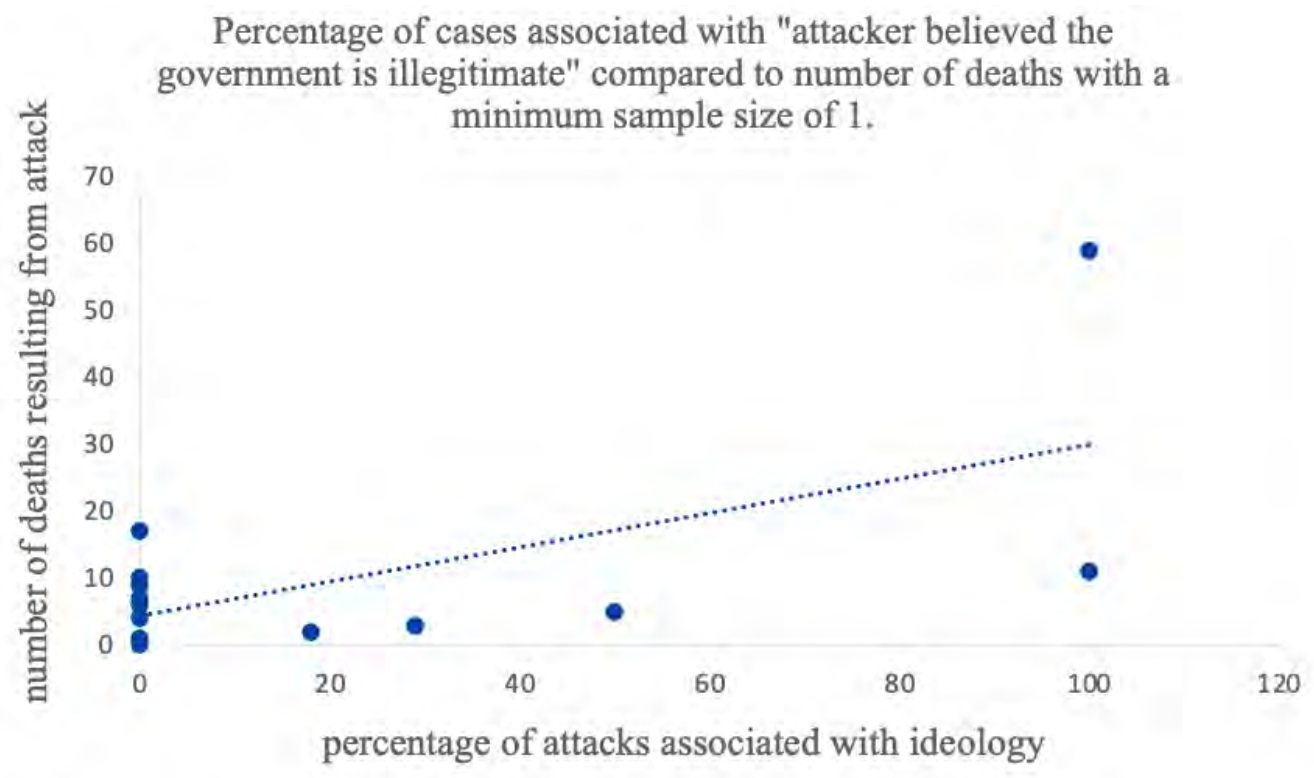

Figure 11. Percentage of cases associated with "attacker believed the government is illegitimate" compared to number of deaths with a minimum sample size of 1

in league with a global Jewish conspiracy. Although there was variation among conspiracy theories, they all adhered to popular conspiracy theories commonly referenced among domestic RW extremist conspiracy theorists. This correlation suggests not only that attackers who believe in conspiracy theories were more likely to carry out more violent attacks as a result of those beliefs, but also that the common domestic RW conspiracy theories popularized by radical domestic RW influencers played a role in motivating these attackers to commit extremist violence.

An attacker classified as "attacker was motivated by a political or financial grievance" latched onto a single issue they perceived as unjust as motivation for their attack. The majority of attackers in this category referenced either gun control legislation or immigration legislation as the reason for their attack. A minority of attackers cited other federal regulations which had a detrimental effect on their business and personal finances. Many attackers who cited immigration legislation as their primary grievance also cited racial supremacist beliefs, although the two aspects of ideology remain mutually exclusive. In every case, the attacker believed they had been let down by the legislature and that legal or political action would be ineffective. Some attackers cited multiple failed attempts to reverse the legislation legally, however the majority referenced no legal action taken on their part to adjudicate their grievance. The correlation between "attacker was motivated by a political or financial grievance" and the number of deaths suggests that attackers with deeply held political beliefs at odds with the current nature of US legislation or with vested 
financial interest in products likely to be regulated by the US government are more likely to carry out deadlier attacks than attackers whose political views are less ingrained or whose financial well-being is less likely to be affected by new legislation.

To be included in the "attacker glorified past domestic RW extremist attacks" aspect of ideology, an attacker had to reference one or more previous instances of domestic RW extremist violence as motivation to carry out an attack. The most commonly referenced instances of domestic RW extremist violence were the Waco and Ruby Ridge stand offs as well as the Murrah Federal Building bombing, although others including the Bundy standoff in Oregon or various school shootings were referenced as well. Attackers either cited these instances as examples of government corruption and overreach or as goals of like-minded individuals that they sought to achieve themselves. This correlation suggests that attackers intending to carry out larger attacks are more likely to be familiar with and be motivated by previous instances of domestic RW extremist violence, while attackers intending to carry out smaller attacks may be less familiar with or motivated by them.

The "attacker believes the government is illegitimate" aspect of ideology refers to attackers who believe that the United States government is either an illegal entity or is taking action beyond its legal bounds. The degree to which the United States' actions or the United States itself is perceived as illegal varies by attacker. Many adherents of this ideology also believe in conspiracy theories concerning the legitimacy and nature of power in the United States government. The correlation between the "attacker believes the government is illegitimate" aspect of ideology and the number of deaths suggests that belief in an illegitimate government either results in the perception of a greater necessity of action by the ideology's adherents, or perhaps the perception of a greater degree of impunity with which an attacker is able to justifiably act.

Analysis of the surveyed attacks revealed that for every attack for which the identity of the attacker was known, the primary attacker was always male. In some cases involving attacks carried out by groups, members of the group were female; however, the primary perpetrators of violence in group attacks were always male. The Capitol attack on January 6, 2021, complicates this classification, as the participants included female and male adherents to a variety of domestic RW ideologies. However, this still suggests that participation in extremist political violence may be a uniquely male phenomenon. It is possible that the identities of some or all of the unidentified perpetrators of attacks are female, however as every attack in which the perpetrator remains unknown resulted in 0 deaths, this may still indicate that extremist violence correlates with the male gender. 


\section{Conclusion}

$\mathrm{R}$

esearch proved the hypothesis: the attackers' ideology correlates with the number of deaths resulting from domestic RW extremist attacks in the United States between 2000 and 2020. In total, eight aspects of domestic RW extremist ideology were found to correlate with the number of deaths when analyzing samples resulting in any number of deaths. However, confidence in those findings is prevented by the small number of cases available for analysis in attacks resulting in more than three deaths. Despite the fact that these domestic RW extremist aspects of ideology were found to correlate at a 0.05 degree of significance, the low number of attacks resulting in four or greater deaths associated with them precluded their inclusion in the results of this study. Greater confidence in these findings requires a greater availability of samples of attacks resulting in four or more deaths. While one hopes data of this sort remains rare, it would be irresponsible for the researcher or policy maker to doubt its eventuality. The affected aspects of ideology include: "attacker glorified their own death," at $r(4)=0.9262, P=0.0238$; "attacker shared intentions before the attack," at $r(4)=0.9197, P=0.0270$; "attacker was proud of attack" at $r(7)=0.7979$, $P=0.0176$; "attacker was socially isolated" at $r(7)=0.8595, \mathrm{P}=0.0062$; "attacker was motivated by conspiracy theories" at $r(12)=0.6212, P=0.0235$; "attacker was motivated by a political or financial grievance" at $r(12)=0.8080$, $P=0.0008$; "attacker glorified past domestic RW extremist attacks" at $r(12)=0.7211, P=0.0054$; and "attacker believed the government is illegitimate" at $r(12)=0.9343, P=0.0001$.

The aspect of ideology "attacker justified violence" was found to correlate significantly at $r(3)=0.9750$, $P=0.0250$ not only when the number of deaths associated with seven or more attacks were included, but continued to correlate significantly when analyzing the number of deaths associated with three or more attacks at $r(4)=0.9826$, $P=0.0270$ and when analyzing the number of deaths associated with two or more attacks at $r(7)=0.7660, P=0.0267$. The significant correlation between "attacker justified violence" and the number of deaths associated with at least seven attacks provides sufficient confidence in the results to prove the hypothesis, the persistent significant correlation of "attacker justified violence" with the number of deaths associated with three or more and two or more attacks respectively indicates that the correlation remains strong even when attacks resulting in a relatively high number of deaths are compared. The absence of significant correlation between "attacker justified violence" and the number of deaths associated with one or more attacks demonstrates the distortive effect only a small number of attacks (in this case five attacks) associated with a high number of deaths (in this case 11 or more) can have on the data.

That is to say that this study does not disprove correlation between "attacker glorified their own death," "attacker shared intentions before the 
attack," "attacker was proud of attack," "attacker was socially isolated," "attacker was motivated by conspiracy theories," "attacker was motivated by a political or financial grievance," "attacker glorified past domestic RW extremist attacks," or "attacker believed the government is illegitimate" and the number of deaths resulting from domestic RW extremist attacks. More data for attacks resulting in a high number of deaths (four or more) is necessary to prove or disprove this possible correlation.

\section{Implications of Findings}

Although many of the aspects of ideology found to correlate with a high number of deaths (four or more) are specific to domestic RW extremist ideology, the only finding this study can report with any confidence, the correlation between the number of deaths and "attacker justified violence" is not. This suggests that the ideology most associated with the number of deaths resulting from domestic RW extremist attacks is not associated with domestic RW extremist ideology alone, but could possibly be associated with extremism of any political motivation. More data for domestic RW extremist attacks resulting in a high number of deaths (four or more) is necessary to corroborate or disprove this claim.

For the purposes of CVE, the findings suggest that methods to nullify the greatest correlative factor of domestic RW extremist violence could also be effective at CVE of any political motivation, although additional studies should be carried out to corroborate this. The findings further indicate that a counter messaging strategy to combat perceptions of the justification to commit violence (for example to defend or take revenge on a specific ethnic group) would be effective at CVE. The twin problems of both real and imagined oppression of various groups in the United States will frustrate this strategy and continue to exacerbate extremism as they have previously done. Meaningful and effective strategies to resolve these issues should be taken not only for their own sake but also to curb the rise in extremism witnessed in the United States in the $21^{\text {st }}$ century.

\section{Limitations}

Although this study strives to accurately explain the relationship between ideology and violence, its findings necessarily suffer from several limitations. First, because this study focuses on domestic RW extremist ideology and violence in the United States between 2000 and 2020, it represents only a narrow view of RW extremist ideology and violence as a whole. RW extremist ideology exists in many forms in many countries and has adapted to local political climates for generations. RW extremist violence, likewise, manifests in numerous forms around the world with a wide degree of varying motivations and goals. It should be noted that organizations as widely varied as the $\mathrm{Ku}$ Klux Klan and Al-Qaeda represent RW extremist organizations albeit from different countries and politico-religious backgrounds. New groups like QAnon and the Proud Boys further differenti- 
ate the field of domestic RW Extremist organizations and their motivating ideologies. Even in the United States, events like 9/11 vastly affected the political milieu in which these ideologies manifest. It is entirely possible that the contemporary growth in domestic RW extremist activity in the United States is largely a reaction to the events of $9 / 11$ and subsequent reactive legislation.

Furthermore, because this study focuses only on the relationship between ideology and violence, it ignores other factors which contribute to violence such as psychology or economics. In addition, due to its method of sampling, this study only investigated attacks that were carried out, reported in news media and subsequently collected by the GTD. Attacks that were planned but never carried out, attacks that failed to be classified as terrorism or as RW extremist by the GTD and which did not include aspects of domestic RW extremist ideology, were not included in the study. Ideologically ambiguous attacks which included aspects of domestic RW extremist ideology were included for analysis, but the possibility of a mischaracterization of an attack remains present. Because the ideologies collected for examination in this study were gathered from primary source documents and in many cases not directly from the people who expressed them, it is possible that they have been represented in a way that does not reflect their original meaning. Finally, due to the inherent wait time in analysis and inclusion of data in the GTD, attacks occurring after January 2020 were not included in this study. Given the current climate of rapidly changing domestic RW extremist ideology, this inherent lag in analysis represents an "Achilles' heel" of the GTD and a significant barrier to future timely research. Efforts should be made to decrease this lag time if future analyses are to have any hope of keeping pace.

\section{Future Research}

This study identified several avenues in which future research could prove to be beneficial. First, additional correlative studies comparing domestic RW extremist ideology and the number of deaths resulting from domestic RW extremist attacks should be carried out using larger samples for attacks resulting in four or more deaths. As waiting until more RW extremist attacks resulting in four or more deaths occur is both untenable and disturbing, a methodology surveying RW extremist violence across a wider sample of countries should be adopted. Care should be taken in selecting countries to include, however, as RWE adheres to widely different ideologies across cultures. Ideally countries with similar milieus of RW extremist ideology such as Canada, Australia, or England would be included in the analysis; however, meaningful data could be discovered by comparing RW extremist ideology across countries with dissimilar cultures. Findings of such a study might not only illuminate the differences in effective CVE strategies between domestic RWE in the United States and other forms of RW extremism, such as Islamic extremism, but could also highlight avenues in which the strat- 
egies may converge, identifying possible force multipliers for investments in CVE. Additionally, further studies with shorter sample periods should be conducted to determine how the correlation between ideology and violence changes over time.

Another fruitful avenue of research would be to compare left-wing extremism with violence in the United States to determine if similar ideologies motivate those spectra of extremism compared to domestic RW extremism. If the data is similar to the findings of this study, a clear pathway for future efforts at CVE would be revealed and valuable information describing the nature of extremism and its psychological drivers could be illuminated.

Furthermore, for future research to be able to maintain pace with the current rapidly changing nature of domestic RWE, databases analyzing the effects of such movements, like the GTD, require increases in funding and staffing commensurate with their task. Con- versely, new databases focusing solely on domestic extremism in the United States should be developed to alleviate this strain on the GTD. This is a hurdle present for all researchers of extremism in the United States. The increased domestic RW extremist activity witnessed over the past few years in the United States makes clear that the problem is both growing and changing at an alarming rate. Increasingly, extremists are more politically engaged, autonomously organized, resistant to counter narratives and cooperative with extremists adhering to similar ideologies. In time, movements like QAnon may come to represent a paradigm shift in domestic RWE after which extremists operate more independently, organize on a larger scale, reflect the stated or subliminal beliefs of serving political figures, and even occupy political office themselves at a significantly higher rate. Increased political attention and data collection is necessary to support innovative future research and subsequent legislation on this highly volatile public security issue.

J. J. Brookhouser is a senior researcher at Parhelion Group, a defense contractor specializing in intelligence collection management, analytics and security consulting. Before Parhelion, he worked in the spheres of anthropological research and investigative journalism, conducting studies on culture, politics and extremism in myriad countries across five continents, frequently under hazardous conditions. He is conversant in five languages including Mandarin and Arabic and spent a year as an Army Special Forces candidate before earning his M.A. in Intelligence Studies from the American Military University's School of Security and Global Studies. The author can be reached at J.brookhouser@parheliongroup.com 


\section{References}

Adams, J., and Roscigno, V. J. 2005. "White Supremacists, Oppositional Culture and the World Wide Web." Social Forces 2, no. 84: 759-778.

Aho, J. A. 1990. The Politics of Righteousness: Idaho Christian Patriotism. Seattle: University of Washington Press.

Alexander, C. 2017. "Terrorism Challenges Facing the Trump Administration." Security Magazine RSS. Security Magazine (28 August 2017). https://www.secu ritymagazine.com/articles/87681-terrorism-challenges-facing-the-trump-admin istration.

Althusser, L. 1970. Lenin and Philosophy and Other Essays. New Delhi, India: Aakar Books.

"Are You a Patriot Or a Terrorist? Intensifying Domestic Repression." Earth First! 22, no. 1 (23 December 2001).

Art, D. 2006. The Politics of the Nazi Past in Germany and Austria. New York: Cambridge Univ. Press.

Asch, Solomon. 1958, "A Study of Conformity." Experiment. http://www.age-ofthe-sage.org/psychology/social/asch_conformity.html

Barkun, Michael. 1994. Religion and the Racist Right. Chapel Hill: UNC Press.

Barkun, Michael. 1995. "Militias, Christian Identity \& The Radical Right," Christian Century, no. 2 (August): 738-781.

Barkun, Michael. 2013. "A Culture of Conspiracy: Apocalyptic Visions in Contemporary America." from Comparative Studies in Religion and Society, 2nd edition. Berkeley, CA: University of California Press.

Baudrillard, Jean. 2002. The Spirit of Terrorism and the Requiem for the Twin Towers, New York: Verso.

Bell, D. 2002. The Dispossessed. New York: Harper \& Row.

Berezin, M. 2009. Illiberal Politics in Neoliberal Times: Culture, Security and Populism in the New Europe. New York: Cambridge Univ. Press

Berger, Peter L., and Luckmann, Thomas. 1967. "The Social Construction of Real- 
ity: A Treatise in the Sociology of Knowledge." Anchor 1967: 178.

Berlet, Chip, and Lyons, Matthew. 1995. "Militia Nation." The Progressive, no. 25 (June): 8-11.

Biernatzki, W.E. 2002. “Terrorism and Mass Media," Communication Research Trends 1, no. 21: 1-44.

Bittner, Egon. 1963. "Radicalism and the Organization of Radical Movements," American Sociological Review 28, no. 4 (December): 928-940.

Bjelopera, Jerome P. 2014. "Countering Violent Extremism in the United States." Congressional Research Service (19 February 2014).

Bjelopera, Jerome P. 2017. "Domestic Terrorism: An Overview." Congressional Research Service (21 August 2017).

Bjelopera, Jerome P. 2012. "The Domestic Terrorist Threat: Background and Issues for Congress.” Congressional Research Service (12 May 2012).

Blanquart, Gabrielle, and David M. Cook. 2013. "Twitter Influence and Cumulative Perceptions of Extremist Support: A Case Study of Geert Wilders." Edith Cowan University Research Online (December).

Blee, Kathleen M., and Kimberly A. Creasap. 2010. "Conservative and Right-Wing Movements." Annual Review of Sociology 36, no. 1:269-86. https://doi.org/10.1146/ annurev.soc.012809.102602.

Boggs, Carl, and Tom Pollard. 2006. "Hollywood and the Spectacle of Terrorism." NewPoliticalScience28, no.3:335-51.https://doi.org/10.1080/07393140600856151.

Borrowman, S. 1999. "Critical Surfing: Holocaust Deniability and Credibility on the Web." College Teaching 2, no. 47: 44-54.

Bowman-Grieve, Lorraine. 2013. "A Psychological Perspective on Virtual Communities Supporting Terrorist \& Extremist Ideologies as a Tool for Recruitment." Security Informatics 2, no. 1. https://doi.org/10.1186/2190-8532-2-9.

Boyd, R. 2000. "Representing Political Violence: The Mainstream Media and the Weatherman 'Days of Rage.” American Studies 1, no. 41: 141-164.

Brannan, David. 2006. Violence, Terrorism, and the Role of Theology: Repentant and Rebellious Christian Identity. St. Andrew's University, Scotland. 
Buzan, Barry, Waever, Ole, and de Wilde, Jaap. 1998. Security: A New Framework for Analysis. Boulder: Lynne Rienner.

Byrne, D. N. 2007. "The Future of (the) "Race": Identity, Discourse, and the Rise of Computer-Mediated Public Spheres." In A. Everett (ed.), Learning Race and Ethnicity: Youth and Digital Media. Cambridge, Mass: MIT Press.

Carpenter, Nathan. 2019. "The Ad Hoc Federal Crime of Terrorism: Why Congress Needs to Amend the Statute to Adequately Address Domestic Extremism." St. John's Law Review 92, no. 393.

Carpenter, S. J., Jacobson, M., and Levitt, M. 2009. "Rewriting the Narrative: An Integrated Strategy for Counter-Radicalization." Washington D.C.: Washington Institute for Near East Policy. Retrieved from https://www.washingtoninstitute. org/uploads/Documents/pubs/PTF2-Counterradicalization.pdf.

Carruthers, S.L. 2011. The Media at War. New York: Palgrave Macmillan.

Center for American Progress-Think Progress. 2012.

Chan, Jason, Ghose, Anindya, and Seamans, Robert. 2013. "The Internet and Hate Crime: Offline Spillovers from Online Access.” SSRN Electronic Journal 2013. https://doi.org/10.2139/ssrn.2335637.

Chermak, Steven M., Joshua D. Freilich, William S. Parkin, and James P. Lynch. 2011. "American Terrorism and Extremist Crime Data Sources and Selectivity Bias: An Investigation Focusing on Homicide Events Committed by Far-Right Extremists." Journal of Quantitative Criminology 28, no. 1 (December): 191-218. https://doi.org/10.1007/s10940-011-9156-4.

Chomsky, Noam, and Achcar, Gilbert. 2007. Perilous Power: The Middle East and U.S. Foreign Policy; Dialogues on Terror, Democracy, War, and Justice. Boulder.

Corbin, Caroline Mala. 2017. "Terrorists Are Always Muslim but Never White: At the Intersection of Critical Race Theory and Propaganda." Fordham Law Review 86, no. 2. http://ir.lawnet.fordham.edu/flr/vol86/iss2/5.

Corman, S. R. 2016. The Narrative Rationality of Violent Extremism. Social Science Quarterly 1 (Wiley-Blackwell), no. 97: 9-18. doi:10.1111/ssqu.12248

Cotter, J.M. 1999. "Sounds of Hate: White Power Rock and Roll and the Neo-Nazi Skinhead Subculture." Terrorism \& Political Violence 11(2): 111-140. 
Crothers, Lane. 2003. Rage on the Right: The American Militia Movement from Ruby Ridge to Homeland Security (Lanham, MD: Rowman and Littlefield.

Cunningham, Karla J. 2007. “Countering Female Terrorism." Studies in Conflict \& Terrorism 30, no. 2: 113-29. https://doi.org/10.1080/10576100601101067.

Daniels, J. 2009. Cyber Racism: White Supremacy Online and the New Attack on Civil Rights. Lanham, MD: Rowman \& Littlefield Publishers, Inc.

de Puy Kamp, Majlie, and Glover, Scott. "Right-Wing Extremists and Their Supporters Use Christian Website to Raise Funds." Cable News Network. January 20, 2021. Accessed February 23, 2021. https://www.cnn.com/2021/01/19/us/givesend-go-extremism-invs/index.html.

de Roy van Zuijdewijn, J., and Bakker, E. 2016. "Analyzing Personal Characteristics of Lone-Actor Terrorists: Research Findings and Recommendations." Perspectives on Terrorism 2, no. 10. Retrieved from International Security \& Counter Terrorism Reference Center.

Dean, G., Bell, P., and Newman, J. 2012. "The Dark Side of Social Media: Review of Online Terrorism.” Pakistan Journal of Criminology 1, no. 4.

Decker, S. H. and D.C. Pyrooz. 2015. "I'm Down for a Jihad': How 100 Years of Gang Research Can Inform the Study of Terrorism." Perspectives on Terrorism 1, no. 9: 104-112.

Deutsch, Karl. 1961. "Social Mobilization and Political Development." American Political Science Review 55, No. 3 (September): 493-514.

Diangelo, Robin. 2011. "White Fragility." International Journal of Critical Pedagogy 3, no. 3: 54-70.

DiAngelo, R. 2006. "My Race Didn’t Trump my Class: Using Oppression to Face Privilege.” Multicultural Perspectives 1, no. 8: 51-56.

DiAngelo, Robin J. 2010. "Why Can't We All Just Be Individuals? Countering the Dis-course of Individualism in Anti-racist Education." InterActions: UCLA Journal of Education and Information Studies 1, no. 6. Retrieved from http://escholarship. org/uc/item/5fm4h8wm.

Dimaggio, A.R. 2009. When Media Goes to War: Hegemonic Discourse, Public Opinion and the Limits of Dissent. New York: Monthly Review Press. 
Doskoch, Peter. 1995. “The Mind of the Militias." Psychology Today. (July/August): 12-16.

Ducol, Benjamin, Martin Bouchard, Garth Davies, Marie Ouellet, and Christine Neudecker. 2016. "Assessment of the State of Knowledge: Connections between Research on the Social Psychology of the Internet and Violent Extremism." The Canadian Network for Research on Terrorism, Security, and Society 16, no. 5 (May).

Dudek, P., and Jaschke, H.-G. 1981. Revolte von rechts: Anatomie einer neuen Jugendpresse. Frankfurt/Main New York: Campus-Verlag.

Dudek, P., and Jaschke, H.-G. 1982. Jugend rechtsaussen: Analysen, Essays, Kritik. Bensheim: Päd. Extra Buchverlag.

Dudek, P., and Jaschke, H.-G. 1984. Entstehung und Entwicklung des Rechtsextremismus in der Bundesrepublik: zur Tradition einer besonderen politischen Kultur. Opladen: Westdeutscher Verlag.

Erbschloe, Michael. 2019. Extremist Propaganda in Social Media: A Threat to Homeland Security. Boca Raton, FL: CRC Press, Taylor \& Francis Group.

Empowering Local Partners to Prevent Violent Extremism in the United States, August 2011.

Feagin, J. R., and Feagin, C. 1993. Racial and Ethnic Relations (4th ed.). Englewood Cliffs, NJ: Prentice Hall.

Fielding, N. 1981. The National Front. London: Routledge and Kegan Paul.

Finlay, W. M. L. 2007. “The Propaganda of Extreme Hostility: Denunciation and the Regulation of the Group." British Journal of Social Psychology 46, no. 2: 323-41. https://doi.org/10.1348/014466606x113615.

Fleras, A., and Elliott, J. 2002. Engaging Diversity: Multiculturalism in Canada. Toronto: Nelson Thomson Learning.

Flowere, Stephen E. 1981. "Revival of Germanic Religion in Contemporary AngloAmerican Culture." Mankind Quarterly 3, no. 21 (Spring 1981).

Fortney, N. D. 1977. “The Anthropological Concept of Race." Journal of Black Studies 1, no. 8: 35-55.

Freedman, D., Pisani, R., and Purves, R. (2007). Statistics (international student 
edition). Pisani, R. Purves, 4th Ed. WW Norton \& Company, New York.

Futrell R, Simi P, and Gottschalk S. 2006. "Understanding Music in Movements: The White Power Music Scene.” Social. no. 47: 275-304

Futrell, R. and Simi, P. 2012. "The Sound of Hate [Op-ed].” New York Times, 8 August 2012. http://www.nytimes.com/2012/08/09/opinion/the-sikh-temple-killersmusic-of-hate.html

Gage, B. 2011. "Terrorism and the American Experience: A State of the Field." Journal of American History 98, no. 1 (January): 73-94. https://doi.org/10.1093/ jahist/jar106.

Gerstenfeld P. 2003. "Hate Online: A Content Analysis of Extremist Internet Sites." Anal. Soc. Issues Public Policy, no. 3:29-44.

Gewirtz, J. L., and Baer, D. M. 1958. "The Effect of Brief Social Deprivation on Behaviors for a Social Reinforcer." The Journal of Abnormal and Social Psychology 1, no. 56: 49. doi:10.1037/h0047188

Gingrich, Newt. 1995. To Renew America. New York: Harper Collins.

Githens-Mazer, J. 2012. "The Rhetoric and Reality: Radicalization and Political Discourse." International Political Science Review 5, no. 33: 556-567.

Glaser, B. 1992. "Basics of Grounded Theory Analysis." Mill Valley, CA: Sociology Press.

Glaser, B. 1978. "Theoretical sensitivity: Advances in the methodology of grounded theory." Mill Valley, CA: Sociology Press.

Glaser, B., and Strauss, A. 1967. "The Discovery of Grounded Theory: Strategies for Qualitative Research.” Mill Valley, CA: Sociology Press.

Griffin, M. 2010. “Media Images of War.” Media, War \& Conflict 1, no. 3: 7-41.

Grumke, Thomas. 2017. "Globalized Anti-Globalists. The Ideological Basis of the Internationalization of Right-Wing Extremism." Perspective Politics.

Haller, J. S., Jr. 1971. Outcasts from Evolution: Scientific Attitudes of Racial Inferiority 1859-1900. Chicago: University of Illinois Press.

Hammond, P. 2007. Media, War and Postmodernity. London: Routledge. 
Healy, Timothy, J. Director, Terrorist Screening Center, Federal Bureau of Investigation, Statement before the House Judiciary Committee, Washington, D.C., March 24, 2010.

Heim, J. 2012. "Wisconsin Shooter Embraced 'Hate Rock." Washington Post, 8 August 2012 .

Hoffman, B. 2003. Al Qaeda, Trends in Terrorism, and Future Potentialities: An Assessment. Santa Monica: RAND.

Hoffman, Bruce. 2006. Inside Terrorism, Revised \& Enlarged. Columbia University Press.

Horgan, J. 2005. The Psychology of Terrorism. London, England: Routledge.

Hoskins, A. and O'Loughlin, B. 2007. Television and Terror: Conflicting Times and the Crisis of News Discourse. Hampshire, UK: Palgrave Macmillan.

Intelligence Report [formerly titled Klan Watch Intelligence Report]. 1998. (fall). Montgomery, AL: Southern Poverty Law Center.

Jenkins, P. 2003. Images of Terror: What We Can and Can't Know About Terrorism. New York: Aldine de Gruyter.

Johnson, H.B., and Shapiro, T.M. 2003. "Good Neighborhoods, Good Schools: Race and the "Good Choices" of White Families." In Doane, A.W \& Bonilla-Silva, E. (eds). White Out: The Continuing Significance of Racism (pp. 173-187). New York: Routledge.

Joosse, P. 2007. "Leaderless Resistance and Ideological Inclusion: The Case of the Earth Liberation Front." Terrorism and Political Violence, no. 19: 351-368.

Kailemia, W. 2016. "The Spectacle of Terrorism: Exploring the Notions of 'Blind Acting Out' and 'Phatic Communication."' Journal of Terrorism Research 2, no. 7. doi: $10.15664 /$ jtr.1192

Kaplan, Jeffrey. 1995. "Right Wing Violence in North America." Terrorism and Political Violence (March).

Keatinge, Tom, Florence Keen, and Kayla Izenman. 2019. "Fundraising for RightWing Extremist Movements." The RUSI Journal 164, no. 2: 10-23. https://doi.org/ 10.1080/03071847.2019.1621479. 
Klein, Adam G. 2010. A Space for Hate: The White Power Movement's Adaptation Into Cyberspace. Litwin Books.

Klein, Adam. 2012. "Slipping Racism into the Mainstream: A Theory of Information Laundering." Communication Theory 22, no. 4: 427-48. https://doi.org/10. 1111/j.1468-2885.2012.01415.x.

Koehler, Daniel. 2014. "Right-Wing Extremist Radicalization Processes: The Formers' Perspective." Journal EXIT Deutschland (January).

Landes, Richard. 2006. "Millenarianism and the Dynamics of Apocalyptic Time, Expecting the End: Millennialism." In Social and Historical Context. Ed. Newport, Kenneth, and Gribben, Crawford. Waco: Baylor University Press.

Langauir, Gavin I. 1990. Toward a Definition of Anti-Semitism. Berkeley: University of California Press.

Laqueur, W. 1999. New Terrorism: Fanaticism and the Arms of Mass Destruction. New York: Oxford University Press.

Latour, B. 1996. “On Actor-Network Theory: A Few clarifications." Soziale Welt, no. 47: 369-381.

Larsson, A. O. 2014. "Everyday Elites, Citizens, or Extremists." Journal of Media and Communication Research 56, no. 30: 61-78.

Leader, S.H. and Probst, P. 2003. "The Earth Liberation Front and Environmental Terrorism." Terrorism and Political Violence, no. 15: 37-58.

Levin B. 2002. "Cyberhate: a legal and historical analysis of extremists' use of computer networks in America." American Behavioral Scientist No. 45:958-88.

Levitt, Matthew. 2017. "Defeating Ideologically Inspired Violent Extremism." Transition 2017 Policy Notes for the Trump Administration, no. 37 (March).

Lewis, J. 2005. Language Wars: The Role of Media and Culture in Global Terror and Political Violence. London: Pluto.

Lewis, J. 2008. “The Role of the Media in Boosting Military Spending." Media, War and Conflict 1, no. 1: 108-117.

Lipset, S.M. 1959. "Democracy and Working-Class Authoritarianism." American Sociology Review 4, no 24:482-501 
Lipset, Seymour M. 1981 [1960]. Political Man, Expanded Edition. Baltimore: The Johns Hopkins University Press.

Lipset, Seymour Martin. 1987. "Blacks and Jews: How Much Bias?” Public Opinion 10, no. 2 (July/August): 4-5 and 57.

Mallea, P. 2011. Fearmonger. Toronto: Lorimer.

Mayntz, R. 2004. "Organizational Forms of Terrorism: Hierarchy, Terrorism, or a Type sui generis?” MPIFG Discussion Paper, No 04/4.

McDonald, M. 2011. The Armageddon Factor: The Rise of Christian Nationalism in Canada (2nd Ed.). Toronto: Vintage.

McIntosh, P. 1988. "White privilege and male privilege: A personal account of coming to see correspondence through work in women's studies." In M. Anderson and P. Hill Collins (Eds.), Race, class, and gender: An anthology (pp. 94-105). Belmont, CA: Wadsworth.

Merrill, Karen R. 1999. "In Search of the Federal Presence in the American West." Western Historical Quarterly 30, No. 4, (Winter): 450.

Michael, George. 2003. Confronting Right Wing Extremism and Terrorism in the USA. Routledge.

Midlarsky, M.I., Crenshaw, M. and Yoshida, F. 1980. "Why Violence Spreads: The Contagion of International Terrorism." International Studies Quarterly 2, no. 24: 262-298.

Milgram, S. 1974. “The Perils of Obedience." Harper's Magazine 1974.

Miller, Erin, LaFree, Gary, and Dugan, Laura. 2019. "Global Terrorism Database Codebook: Inclusion Criteria and Variables." National Consortium for the Study of Terrorism and Responses to Terrorism. (October) https://start.umd.edu/gtd/down loads/Codebook.pdf.

Mogensen, K. 2008. “Television Journalism During Terror Attacks." Media, Conflict \& War 1, no. 1:31-49.

Moghaddam, Fathali M. 2008. "Multiculturalism and Intergroup Relations: Psychological Implications for Democracy in Global Context." American Psychological Association: 94-95. 
Mudde C, Ed. 2005. Racist Extremism in Central and Eastern Europe. London: Routledge.

Norris, Pippa, Kern, Montague, and Just, Marion R. 2003. Framing Terrorism. Routledge.

Nacos, Brigitte L. 2006. "Terrorism/Counterterrorism and Media in the Age of Global Communication.” United Nations University Global Seminar Second Shimame-Yamaguchi Session (5 August 2006).

Nacos, B.L. 2007. Mass-Mediated Terrorism: The Central Role of the Media in Terrorism and Counterterrorism. Lanham, MD: Rowman \& Littlefield.

Nacos, B.L., Bloch-Elkon, Y. and Shapiro, R.Y. 2011. Selling Fear: Counterterrorism, the Media and Public Opinion. Chicago: Chicago University Press.

Neumann, Peter R. 2013. "Options and Strategies for Countering Online Radicalization in the United States." Studies in Conflict \& Terrorism 36, no. 6: 431-59. https://doi.org/10.1080/1057610x.2013.784568.

Neumann, P. 2013. “The Trouble with Radicalization." International Affairs 4, no. 89: 873-893.

News networks regularly promote anti-gay Family Research Council on air. 2011. Retrieved from http://equalitymatters.org/factcheck/201112120002.

Norris, J. J. 2017. "Why Dylann Roof is a Terrorist Under Federal Law, and why it Matters." Harvard Journal on Legislation 1, no. 54: 501-541.

Ohlemacher, T.1998. Fremdenfeindlichkeit und Rechtsextremismus: Mediale Berichterstattung, Bevölkerungsmeinung und deren Wechselwirkung mitfremdenfeindlichen Gewalttaten, 1991-1997. Hannover: KfN.

O'Leary, Stephen. 1994. Arguing the Apocalypse: A Theory of Millennial Rhetoric. New York: Oxford University Press.

Ophir, Y., and Weimann, G. 2012. "From Terrorist to Persona: Para-Social Interaction and the ETA Website." Perspectives On Terrorism 1, no. 6: 23-35.

Paletz, D.L. and Vinson, C.D. 1992. In Paletz, D.L. \& Schmid, A.P. (eds) Terrorism and the Media, pp. 1-5. Newbury Park, CA: Sage.

Peltz, Madeline. “The Definitive Guide to Fox News' Treatment of the QAnon 
Conspiracy Theory." Media Matters for America, Media Matters for America, 16 Jan. 2021, www.mediamatters.org/qanon-conspiracy-theory/definitive-guide-foxnews-treatment-qanon-conspiracy-theory.

Perl, R. F. 1997. Terrorism, The Media and The Government.: Perspectives, Trends, and Options for Policymakers. CRS Report of Congress.

Perry, Barbara, and Ryan Scrivens. 2017. "Right Wing Extremism in Canada An Environmental Scan.” https://doi.org/10.1007/978-3-030-25169-7_5.

Picard, R.G. 1986. "News Coverage as the Contagion of Terrorism: Dangerous Charges Backed by Dubious Science." Political Communication 4, no. 3: 385-400.

Picard, R.G., 1991. “The Journalist's Role in Coverage of Terrorist Events." In A. O. Alali and Eke, K.K. (eds.), Media Coverage of Terrorism: Methods of Diffusion, Newbury Park, CA: Sage.

Pierce, W. 1997. “The New World Order." Free Speech [On-line]. Available: www. nat-van.com/free-speech/fs979d.html.

Phillip, Abby. 2015. “The Charleston Magistrate Who Sparked a Debate About Who Is a Victim." Washington Post (21 June 2015), https://www.washingtonpost. $\mathrm{com} /$ national/the-charleston-magistrate-who-sparked-a-debate-about-who-is-avictim/2015/06/21/ef340330-184a-11e5-93b7-5eddc056ad8a_story.html? [https://perma.cc/7WYT-MMYA].

Popper, Karl R. 1966 Conjectures and Refutations: The Growth of Scientific Knowledge. New York: Harper Torchbook.

Popper, Karl R. 1968. Truth, Rationality, and the Growth of Scientific Progress, in Conjectures and Refutations. New York: Harper Torchbook.

Potok, Mark. 2016. “The Year in Hate and Extremism.” Southern Poverty Law Center, 17 February 2016, https://www.splcenter.org/fighting-hate/intelligence-report /2016/year-hate-and-extremism.

PR Newswire. 2012. "Southern Poverty Law Center Intelligence Report Profiles 30 Leaders of the Rising Radical Right." (23 May 2012).

Preston, J., and Schwirtz, M. 2012. "After Shooting, Searching for Clues in the Music of Hate." The New York Times, 6 August 2012.

Quiney, Ruth. 2007. “'Mr. Xerox,” the Domestic Terrorist, and the Victim-Citizen: 
Masculine and National Anxiety in Fightclub and Anti-Terror Law." Law and Literature 19, no. 2 (1 July 2007): 327-54. https://doi.org/10.1525/lal.2007.19.2.327.

Ray, B., and Marsh, G. E. 2001. "Recruitment by Extremist Groups on the Internet." First Monday, Available at: http://ojphi.org/ojs/index.php/fm/article/ view/834/743.

Reid, E, and Chen, H. 2007. "Internet-Savvy U.S. and Middle Eastern Extremist Groups.” Mobilization, no. 12:177-92.

Rogers, M. B., Loewenthal, K. M., Lewis, C. A., Amlôt, R., Cinnirella, M., and Ansari, H. 2007. "The Role of Religious Fundamentalism in Terrorist Violence: A Social Psychological Analysis." International Review of Psychiatry 3, no. 19: 253-262. Retrieved from http://www-tandfonline-com.proxy1.ncu.edu/

Rohner, D., and Frey, B.S. 2007. "Blood and Ink! The Common-Interest-Game Between Terrorists and the Media." Public Choice, no. 133: 129-145.

Saeed, A. 2007. "Media, Racism and Islamophobia: The Representation of Islam and Muslims in the Media." Sociology Compass: 443-462. doi:10.1111/j.17519020.2007.00039.x.

Said, E. 1979. Orientalism. New York, NY: Vintage Books.

Said, E. 1981. Covering Islam: How the Media and the Experts Determine How We See the Rest of the World. New York, NY: Pantheon Books.

Sánchez-Cuenca, Ignacio, and Luis De La Calle. 2009. "Domestic Terrorism: The Hidden Side of Political Violence." Annual Review of Political Science 12, no. 1: 31-49. https://doi.org/10.1146/annurev.polisci.12.031607.094133.

Sardar, Ziauddin, and Davies, Merryl Wyn. 2002. Why Do People Hate America? New York: Disinformation.

Sartre, Jean-Paul. 1948. Anti-Semite and Jew. New York: Schocken Books.

Saucier, Gerard, Laura Geuy Akers, Seraphine Shen-Miller, Goran Kneževié, and Lazar Stankov. 2009. "Patterns of Thinking in Militant Extremism." Perspectives on Psychological Science 4, no. 3: 256-71. https://doi.org/10.1111/j.1745-6924.20 09.01123.x.

Schmid, Alex. 2005. “Terrorism as Psychological Warfare." Democracy and Security 1, no. 2: 137-46. https://doi.org/10.1080/17419160500322467. 
Scott, J.L. 2001. "Media Congestion Limits Media Terrorism." Defense and Peace Economics 3, no. 12: 215-227.

Seib, P., and D. M. Janbek. 2011. Global Terrorism and New Media: The Post al-Qaeda Generation. London and New York: Routledge.

Shanks-Meille, S., and Dobratz, B. A. 1991. "Sick Feminists or Helpless Victims: Images of Women in Ku Klux Klan and American Nazi Party Literature." Humanity and Society 1, no. 15: 72-93.

Sharpe, Tanya Telfair. 2000. “The Identity Christian Movement.” Journal of Black Studies 30, no. 4: 604-23. https://doi.org/10.1177/002193470003000407.

Simi, P., and Futrell, R. 2010. American Swastika: Inside the White Power Movement's Hidden Spaces of Hate. Lanhan, MD: Rowman \& Littlefield Publishers, Inc.

Skoll, Geoffrey R. 2006. "Meanings of Terrorism.” International Journal for the Semiotics of Law - Revue Internationale De Sémiotique Juridique 20, no. 2: 107-27. https://doi.org/10.1007/s11196-006-9038-5.

Sloan, S. 2016. "Placing Terrorism in an Academic and Personal Context: A Case Study of the Oklahoma City Bombing." Social Science Quarterly (Wiley-Blackwell), 97(1). (2016): 65. doi:10.1111/ssqu.12253

Southers, E. 2013. Homegrown Violent Extremism. Waltham, MA: Anderson.

Sprinzak, Ehud. 1991. "The Process of Delegitimization: Towards a Linkage Theory of Political Terrorism." Terrorism and Political Violence 3, no. 1 (Spring): 50-68.

Stanley, Jason. 2021. Quoted in Trudy Rubin, 2021. The violence and conspiracy theories Trump fueled will threaen America long after he leaves. The Philadelphia Inquirer. January $14^{\text {th }}$, 2021. Accessed 23 February 2021. https://www.inquirer.com/ opinion/capitol-trump-inaugural-troops-boogaloo-qanon-proud-boys-20 210114.html.

Stormfront. (n.d.). Retrieved from https://www.stormfront.org/forum/

Stöss, R. 2007. Rechtsextremismus im Wandel. Berlin: Friedrich-Ebert-Stiftung.

Subcommittee on Forests and Forest Health of the Committee on Resources U.S. House of Representatives, Ecoterrorism and Lawlessness on the National Forests (Serial No. 107-83) (in text: Ecoterrorism and Lawlessness), Hearing, February 12, 2002. 
Sullivan, E. 2012. "Sovereign Citizens Are Extremists Watched by FBI." Huffington Post, 6 February 2012.

Thussu, D.K. \& Freedman, D. 2003. Media and the War: Reporting Conflict 24/7. London: Sage.

Tullock, G., 1974. The Social Dilemma: The Economics of War and Revolution. University Publications, Blacksburg, VA.

United States Code of Federal Regulations: 28 C.F.R. Section 0.85.

Vodde, R. 2001. "De-centering Privilege in Social Work Education: Whose Job is it Anyway?” Journal of Race, Gender and Class 4, no. 7: 139-160

Weimann, G. and Winn, C. 1994. The Theater of Terror: Mass Media and International Terrorism. New York: Longman.

Weimann, G. 1987. "Media Events: The Case of International Terrorism." Journal of Broadcasting and Electronic Media 1, no. 31:21-39.

White, R. 1989. "From Peaceful Protest to Guerrilla War: Micromobilization of the Provisional Irish Republican Army." The American Journal of Sociology 6, no. 94: 1277-1302.

White, Richard. 1997. "The Current Weirdness in the West." Western Historical Quarterly 28, no. 1 (Spring): 10.

Wilkinson, Paul. 1997. "The Media and Terrorism: A Reassessment." Terrorism and Political Violence 9, no. 2: 51-64. https://doi.org/10.1080/09546559708427402.

Zhou, Yilu, E. Reid, Jialun Qin, Hsinchun Chen, and Guanpi Lai. 2005. “US Domestic Extremist Groups on the Web: Link and Content Analysis." IEEE Intelligent Systems 20, no. 5: 44-51. https://doi.org/10.1109/mis.2005.96. 


\section{Appendix A: List of Identified Aspects of Ideology}

Attack was carried out by a single actor.

Attack was carried out by more than one person.

Attack was incited by a social or legal event involving the attacker.

Attack was motivated by conspiracy theories.

Attack was racially motivated.

Attack was religiously motivated.

Attack was retaliation for a perceived slight.

Attacker adhered to conflicting ideologies.

Attacker believed the government is illegitimate.

Attacker believed they were emasculated.

Attacker carried out extensive planning prior to the attack.

Attacker dehumanized victims.

Attacker engaged in catastrophizing.

Attacker glorified past domestic RWE actors and leaders.

Attacker glorified past domestic RWE attacks.

Attacker glorified their own death.

Attacker glorified violence.

Attacker had a military background.

Attacker had connections with domestic RWE community.

Attacker had history of mental illness.

Attacker has a history of depression.

Attacker has a history of legal problems.

Attacker held anti-abortion beliefs.

Attacker held anti-American beliefs.

Attacker held anti-capitalist beliefs.

Attacker held anti-female beliefs.

Attacker held anti-government beliefs.

Attacker held anti-police beliefs.

Attacker held anti-religious beliefs. 
Attacker held anti-RWE beliefs.

Attacker held anti-TSA beliefs.

Attacker intended to carry out a larger attack.

Attacker justified violence.

Attacker referenced domestic RWE ideology during or after attack.

Attacker shared their intentions before the attack.

Attacker sought to confess after the attack.

Attacker sought to inspire others to action.

Attacker suffered from a troubled childhood.

Attacker suffered from social isolation.

Attacker viewed attack as patriotic.

Attacker was a racial supremacist.

Attacker was an immigrant.

Attacker was anti-Muslim.

Attacker was anti-Semitic.

Attacker was motivated by a political or financial grievance.

Attacker was proud of attack.

Attacker had a history of misconduct

Authorities were warned about attack beforehand. 